\title{
Importance of tropospheric volcanic aerosol for indirect radiative forcing of climate
}

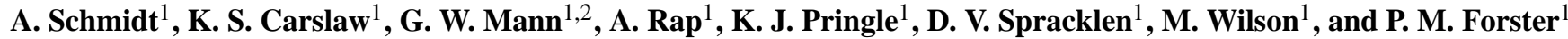 \\ ${ }^{1}$ School of Earth and Environment, University of Leeds, Leeds, LS2 9JT, UK \\ ${ }^{2}$ National Centre for Atmospheric Science, University of Leeds, Leeds, LS2 9JT, UK
}

Correspondence to: A. Schmidt (a.schmidt@leeds.ac.uk)

Received: 12 March 2012 - Published in Atmos. Chem. Phys. Discuss.: 21 March 2012

Revised: 26 July 2012 - Accepted: 8 August 2012 - Published: 16 August 2012

\begin{abstract}
Observations and models have shown that continuously degassing volcanoes have a potentially large effect on the natural background aerosol loading and the radiative state of the atmosphere. We use a global aerosol microphysics model to quantify the impact of these volcanic emissions on the cloud albedo radiative forcing under pre-industrial (PI) and present-day (PD) conditions. We find that volcanic degassing increases global annual mean cloud droplet number concentrations by $40 \%$ under PI conditions, but by only $10 \%$ under PD conditions. Consequently, volcanic degassing causes a global annual mean cloud albedo effect of $-1.06 \mathrm{~W} \mathrm{~m}^{-2}$ in the PI era but only $-0.56 \mathrm{~W} \mathrm{~m}^{-2}$ in the PD era. This non-equal effect is explained partly by the lower background aerosol concentrations in the PI era, but also because more aerosol particles are produced per unit of volcanic sulphur emission in the PI atmosphere. The higher sensitivity of the PI atmosphere to volcanic emissions has an important consequence for the anthropogenic cloud radiative forcing because the large uncertainty in volcanic emissions translates into an uncertainty in the PI baseline cloud radiative state. Assuming a $-50 /+100 \%$ uncertainty range in the volcanic sulphur flux, we estimate the annual mean anthropogenic cloud albedo forcing to lie between $-1.16 \mathrm{~W} \mathrm{~m}^{-2}$ and $-0.86 \mathrm{~W} \mathrm{~m}^{-2}$. Therefore, the volcanically induced uncertainty in the PI baseline cloud radiative state substantially adds to the already large uncertainty in the magnitude of the indirect radiative forcing of climate.
\end{abstract}

\section{Introduction}

The impacts of volcanic eruptions on Earth's radiation budget, the environment and human health have been well doc- umented (e.g., Robock, 2000; Baxter, 2000; Delmelle et al., 2002; Schmidt et al., 2011). Major explosive volcanic eruptions perturb stratospheric aerosol properties and the resulting chemical, microphysical and radiative effects have been the subject of intensive investigation for several decades (a comprehensive review is provided by Robock, 2000). Recent advances include the use of global aerosol microphysics models due to a growing awareness that the evolution of the particle size distribution is critical to determining the magnitude of simulated climate forcings (e.g., Timmreck et al., 2009, 2010). In contrast, the atmospheric and climatic effects of volcanic aerosol released into the troposphere by continuously degassing and sporadically erupting volcanoes (hereafter "volcanic degassing") have only gradually become of greater interest to the geosciences community (Chin and Jacob, 1996; Graf et al., 1997, 1998; Stevenson et al., 2003a; Mather et al., 2003b; Textor et al., 2004; Gassó, 2008; Yuan et al., 2011; Oppenheimer et al., 2011). In their recent review of sulphur degassing from volcanoes, Oppenheimer et al. (2011) concluded that "changes in time and space in this "background" emission could represent an important forcing factor that has yet to be characterized."

Volcanic degassing provides an important natural source of sulphur to the troposphere. Estimates of the global sulphur flux range from $0.75 \mathrm{Tg}(\mathrm{S}) \mathrm{a}^{-1}$ (Kellogg et al., 1972) to $25.0 \mathrm{Tg}(\mathrm{S}) \mathrm{a}^{-1}$ (Lambert et al., 1988). Andres and Kasgnoc (1998) compiled a volcanic sulphur flux inventory that accounts for a flux of $10.4 \mathrm{Tg}(\mathrm{S}) \mathrm{a}^{-1}$ based on flux measurements from 49 continuously and 25 sporadically erupting volcanoes between 1970 and 1997 . The inventory is widely used in atmospheric modelling studies, such as the AEROCOM international model intercomparison (Dentener 

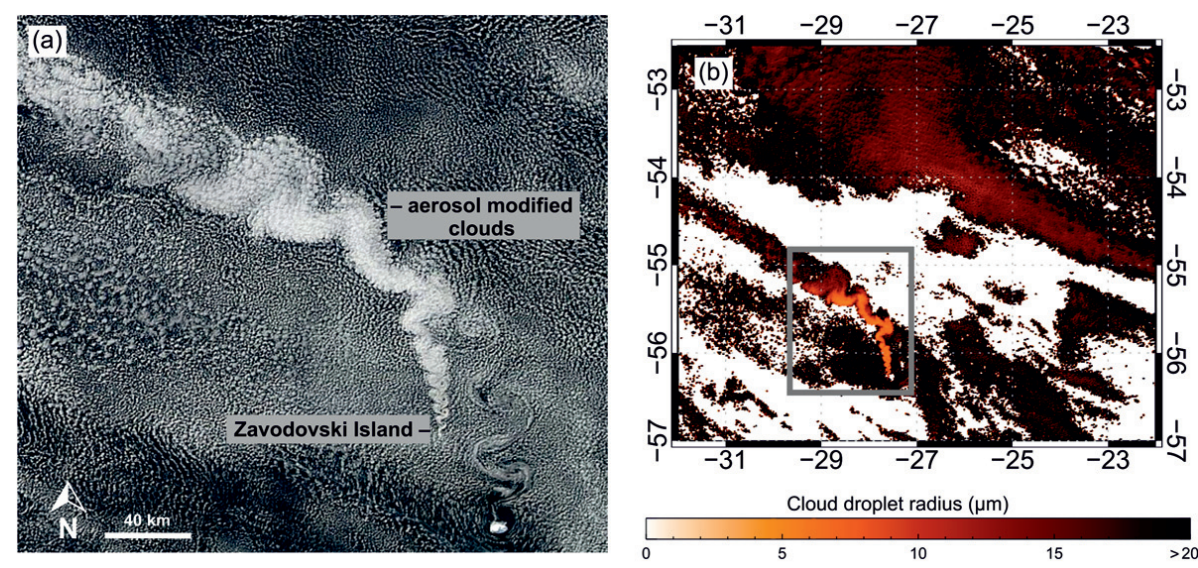

Fig. 1. Satellite retrievals showing that volcanic emissions from Mount Curry volcano on Zavodovski Island (South Sandwich Islands in the Southern Ocean) modified cloud properties and albedo resulting in brighter clouds than the surrounding clouds. (a) Natural-colour image acquired 27 April 2012 by the Moderate Resolution Imaging Spectroradiometer (MODIS) on NASA's Aqua satellite; and (b) cloud droplet effective radius at the top of the clouds calculated from MODIS data. Underlying MODIS image and data provided by Robert B. Simmon, NASA Earth Observatory, and Jeff Schmaltz, LANCE MODIS Rapid Response (http://1.usa.gov/MGA83O).

et al., 2006). For comparison, the other natural sources of sulphur are oceanic dimethyl-sulphide (DMS) with a flux of 13$36 \mathrm{Tg}(\mathrm{S}) \mathrm{a}^{-1}$, biomass burning with a flux of $1-6 \mathrm{Tg}(\mathrm{S}) \mathrm{a}^{-1}$, and land biota/soils with a flux of $0.4-5.6 \mathrm{Tg}(\mathrm{S}) \mathrm{a}^{-1}$ (Penner et al., 2001). Thus, volcanic degassing in the pre-industrial (PI) era accounts for between $18 \%$ and $42 \%$ of the total natural sulphur flux, which dominates in the PI era when anthropogenic sulphur emissions were very low $\left(0.1 \mathrm{Tg}(\mathrm{S}) \mathrm{a}^{-1}\right.$ in the year 1750 in Dentener et al., 2006; $\sim 1 \mathrm{Tg}(\mathrm{S}) \mathrm{a}^{-1}$ in the year 1850 in Lamarque et al., 2010). In contrast, the presentday (PD) atmosphere is dominated by an anthropogenic sulphur flux of $46.4 \mathrm{Tg}(\mathrm{S}) \mathrm{a}^{-1}$ in the year 2000 (Lamarque et al., 2010) and of $57.8 \mathrm{Tg}(\mathrm{S}) \mathrm{a}^{-1}$ in the year 2005 (Smith et al., 2011) hence volcanic degassing presently accounts for around $10 \%$ of the total global sulphur flux (Stevenson et al., 2003a).

Observations show a clear regional impact of volcanic degassing on aerosol concentrations and the micro- and macrophysical properties of clouds. For example, Tu et al. (2004) reported that the long-range transport of sulphur dioxide $\left(\mathrm{SO}_{2}\right)$ from Miyake-jima volcano in Japan provided a significant source of sulphur to the troposphere of the central Pacific. Gassó (2008) used satellite retrievals to show that volcanic sulphur injected into the lowermost troposphere during weakly explosive volcanic eruptions may induce significant aerosol indirect effects via the modification of marine boundary layer clouds. Figure 1 shows that volcanic emissions from Mount Curry volcano on Zavodovski Island (South Sandwich Islands) modified cloud properties and albedo resulting in brighter clouds than the surrounding clouds. Yuan et al. (2011) showed that sulphur emissions emitted from Kilauea's Halema' uma'u Crater on Hawaii affect trade cumulus cloud amount as far as $6000 \mathrm{~km}$ downwind of the volcanic source and cause a regional total shortwave radiative forcing of up to $-20 \mathrm{~W} \mathrm{~m}^{-2}$. Boulon et al. (2011) provided the first observational evidence of the occurrence of aerosol nucleation in the 2010 Eyjafjallajökull (Iceland) volcanic plume at a station more than $2500 \mathrm{~km}$ downwind of the volcanic vent. Hence, volcanic degassing has a strong potential to impact cloud amounts and cloud microphysical properties in the troposphere far away from the actual eruption site.

In general, the climatic impact of volcanic degassing arises through (i) the direct radiative forcing caused by scattering of incoming solar radiation by the additional aerosol and (ii) the indirect radiative forcing caused by the impact of the additional aerosol on cloud condensation nuclei ( $\mathrm{CCN})$, hence cloud droplet number concentrations (CDNC) and the radiative properties of clouds (referred to as aerosol indirect effects; Twomey, 1977; Albrecht, 1989). The anthropogenic aerosol indirect effects represent one of the largest radiative forcings since PI times and also contribute most to the uncertainty in the total anthropogenic radiative forcing (Forster et al., 2007). Forster et al. (2007) estimated a cloud albedo radiative forcing of $-0.7 \mathrm{~W} \mathrm{~m}^{-2}$ with a $5 \%$ to $95 \%$ confidence range of $-0.3 \mathrm{Wm}^{-2}$ to $-1.8 \mathrm{Wm}^{-2}$. This uncertainty is principally derived from a range of modelling studies using different aerosol species and mixtures. The aim of our study is to quantify the magnitude of the cloud albedo effect induced by volcanic degassing using the same metric as the Intergovernmental Panel on Climate Change (IPCC) used in their fourth assessment report (Forster et al., 2007). Aerosol also has other potential effects on clouds, such as the cloudlifetime effect (Albrecht, 1989) and the semi-direct effects (e.g., Hansen et al., 1997) that are more challenging to observe and model (e.g., Lohmann and Feichter, 2005; Forster et al., 2007). We do not attempt to quantify the cloud lifetime effect or semi-direct effects, although we note that Gassó (2008) and Yuan et al. (2011) found cloud changes beyond 
changes to drop-size due to volcanic degassing, which would act to either decrease or increase the radiative forcing hence adding further uncertainty to the total aerosol-cloud effect. However, the necessity to better quantify the effects of volcanic degassing on global $\mathrm{CCN}$ in the troposphere and the subsequent cloud albedo effect has been stressed previously (Robock, 2002; Mather et al., 2003b; Gassó, 2008; Oppenheimer et al., 2011; Yuan et al., 2011).

Previous modelling studies have assessed the relative contribution of volcanic degassing to the global sulphur mass budget (Chin and Jacob, 1996; Stevenson et al., 2003a) as well as its radiative effects (Graf et al., 1997, 1998; Langmann et al., 1998) under PD atmospheric conditions. Graf et al. (1997), amongst others, concluded that volcanic sulphur emissions are at least as important as anthropogenic sulphur emissions with regard to the global sulphur cycle and their contribution to the radiative forcing of climate. Langmann et al. (1998) used a regional chemistry transport model and found that natural sulphur sources such as DMS and volcanoes account for $\sim 34 \%$ of the total direct sulphate aerosol radiative effect over Europe. However, these earlier studies neither assessed the impact of volcanic degassing under PI conditions (when the aerosol background loading was generally lower) nor did they address the role of the uncertainty in the volcanic source strength. Graf et al. (1997) assessed the impact of volcanic degassing on global cloud radiative perturbations based on the sulphate aerosol mass generated in the atmosphere and estimated an annual mean cloud albedo effect that regionally exceeds $-3 \mathrm{Wm}^{-2}$. However, as we showed in our previous modelling of the long-lasting 17831784 AD Laki eruption, impacts on CCN concentrations and $\mathrm{CDNC}$ occur far from the source due to the several days timescale for oxidation of $\mathrm{SO}_{2}$ to sulphuric acid $\left(\mathrm{H}_{2} \mathrm{SO}_{4}\right)$ vapour and subsequent nucleation and growth to $\mathrm{CCN}$ sizes with changes in sulphate mass alone being an inadequate proxy (Schmidt et al., 2010).

Here, we use a global aerosol microphysics model (GLOMAP-mode) (Mann et al., 2010, 2012) together with a radiative transfer code (Edwards and Slingo, 1996) and the volcanic sulphur emission inventory compiled by Andres and Kasgnoc (1998) to address the following questions:

1. Is volcanic degassing an important contributor to global cloud condensation nuclei concentrations and cloud droplet number concentrations in the troposphere in the present-day and the pre-industrial era (see Sects. 3.1 and 3.2)?

2. Does volcanic degassing exert a climatically significant cloud albedo effect in the present-day and the pre-industrial era, and how significant is this contribution in comparison to other natural sulphur sources (see Sect. 3.3)?

3. Given that background aerosol concentrations were generally lower during the pre-industrial era than today and given the uncertainty inherent in the volcanic emission inventories, what uncertainties arise for the assessments and magnitude of both the anthropogenic cloud albedo forcing and the total cloud albedo forcing (see Sect. 3.4)?

\section{Methods}

\subsection{Model description}

The GLObal Model of Aerosol Processes (GLOMAP) is a particle size-resolving global aerosol microphysics model (Spracklen et al., 2005a, b) which is embedded in the chemical transport model TOMCAT (Stockwell and Chipperfield, 1999; Chipperfield, 2006). Here, we use the two-moment modal version of the model (GLOMAP-mode) described and evaluated in Mann et al. (2010, 2012). GLOMAP-mode treats microphysical processes such as binary homogeneous nucleation, hygroscopic growth, coagulation, condensation, cloud processing (growth of CCN via aqueous-phase sulphate production in cloud droplets), as well as dry and wet deposition of particles between a few nanometres and several micrometres in size.

The horizontal resolution of the model is $2.8^{\circ} \times 2.8^{\circ}$ with 31 hybrid sigma-pressure levels extending from the surface to $10 \mathrm{hPa}$ in the vertical. The model is driven by meteorological fields specified from European Centre for Medium-Range Weather Forecasts (ECMWF) analyses at 6-h intervals (Uppala et al., 2005; Dee et al., 2011). All simulations were run for twelve months specifying the same meteorological fields for the year 2004 in order to ensure consistency between the runs.

The aerosol size distribution is simulated using seven lognormal modes: hygroscopic nucleation, Aitken, accumulation and coarse modes plus nonhygroscopic Aitken, accumulation, and coarse modes. The aerosol components are sulphate, sea-salt, organic carbon (OC), black carbon (BC) and mineral dust. We run the model with the same parameter set-up described in Mann et al. (2012) except that here coemitted BC/OC use the coarser size settings recommended by Stier et al. (2005), which improves comparisons with the CCN observations compiled by Spracklen et al. (2011). We use the sulphur chemistry scheme as described in Breider et al. (2010) coupled with the TOMCAT chemistry including $\mathrm{O}_{\mathrm{x}}-\mathrm{NO}_{\mathrm{y}}-\mathrm{HO}_{\mathrm{x}}, \mathrm{C} 1-\mathrm{C} 3$ non-methane hydrocarbons and isoprene reactions. Briefly, in the troposphere, gas-phase $\mathrm{H}_{2} \mathrm{SO}_{4}$ is produced via the oxidation of $\mathrm{SO}_{2}$ by the hydroxyl radical $(\mathrm{OH})$ that leads to additional sulphate aerosol mass via vapour condensation and also a greater aerosol number via nucleation. Aqueous-phase sulphate production in cloud droplets is simulated via reactions of dissolved $\mathrm{SO}_{2}$ with dissolved hydrogen peroxide $\left(\mathrm{H}_{2} \mathrm{O}_{2}\right)$ and ozone $\left(\mathrm{O}_{3}\right)$.

The emission inventories for both the PI and the PD runs are as follows: $12.58 \mathrm{Tg}(\mathrm{S}) \mathrm{a}^{-1}$ volcanic $\mathrm{SO}_{2}$ using 
the Andres and Kasgnoc (1998) inventory following recommendations of Dentener et al. (2006) (for details refer to Sect. 2.2); 17.1 $\mathrm{Tg}(\mathrm{S}) \mathrm{a}^{-1}$ DMS (Kettle and Andreae, 2000) assuming a sea-air transfer velocity parameterisation of Nightingale et al. (2000). Sea spray emissions are interactive in the model, driven by the wind speed at each timestep using the Gong (2003) size-resolved source function. Monthlymean emission fluxes from Guenther et al. (1995) drive a transported monoterpene tracer in the model which oxidises to form biogenic secondary organic matter via uptake to the aerosol of a condensable organic tracer (as in Spracklen et al., 2006). Daily varying mineral dust emissions for the year 2000 are included following Dentener et al. (2006). Mineral dust is emitted into the insoluble accumulation and insoluble coarse modes. For the PD runs we additionally included anthropogenic $\mathrm{SO}_{2}$ emissions from Cofala et al. (2005) with $24.1 \mathrm{Tg}(\mathrm{S}) \mathrm{a}^{-1}$ from power stations, 19.6 $\mathrm{Tg}(\mathrm{S}) \mathrm{a}^{-1}$ from industrial processes, $5.7 \mathrm{Tg}(\mathrm{S}) \mathrm{a}^{-1}$ from transportation, and $4.6 \mathrm{Tg}(\mathrm{S}) \mathrm{a}^{-1}$ from domestic consumption. For the $\mathrm{PD}$ runs, monthly varying $\mathrm{SO}_{2}$ emissions from biomass burning are from Van der Werf et al. (2003) and account for $2.1 \mathrm{Tg}(\mathrm{S}) \mathrm{a}^{-1}$. Annual mean BC and OC emissions from fossil fuel and biofuel sources are from Bond et al. (2004), and monthly varying BC and OC emissions from wildfires are from Van der Werf et al. (2003), which in total account for a global flux of $8.0 \mathrm{Tg} \mathrm{a}^{-1}$ for BC and $49.2 \mathrm{Tg} \mathrm{a}^{-1}$ for OC. For the PI runs, we use monthly varying biomass burning $\mathrm{SO}_{2}, \mathrm{BC}$ and $\mathrm{OC}$ emissions for the year 1750 from Dentener et al. (2006) accounting for a total global flux of $1.37 \mathrm{Tg}(\mathrm{S}) \mathrm{a}^{-1}$ for $\mathrm{SO}_{2}, 1.03 \mathrm{Tg} \mathrm{a}^{-1}$ for $\mathrm{BC}$ and $12.8 \mathrm{Tg} \mathrm{a}^{-1}$ for OC. Fossil fuel and biofuel emissions are set to zero in the PI runs.

\subsection{Volcanic emission inventory and uncertainties}

The Andres and Kasgnoc (1998) inventory (Fig. 2) in its original form accounts for a global sulphur flux of $10.4 \mathrm{Tg}(\mathrm{S}) \mathrm{a}^{-1}$. For AEROCOM, the inventory accounts for a global sulphur flux of $12.58 \mathrm{Tg}(\mathrm{S}) \mathrm{a}^{-1}$ (following the recommendations of Graf et al., 1998 and Textor et al., 2004 to scale the inventory). It is known that sub-grid scale nucleation occurs in both volcanic and industrial plumes (Allen et al., 2002; Brock et al., 2002), hence in the model we include $2.5 \%$ of the emitted $\mathrm{SO}_{2}$ as sub-grid sulphate adding to particle number and mass in the accumulation and coarse modes (also used by Stier et al., 2005). Measurements of near-source sulphate particles at several continuously degassing volcanoes indicate a fraction of $1 \%$ to $5 \%$ of the total emitted $\mathrm{SO}_{2}$ (e.g., Allen et al., 2002; Mather et al., 2003a, b, 2004, 2006, 2012; Martin et al., 2008). Luo and Yu (2011) have shown that global CCN number concentrations are sensitive to both the sub-grid sulphate mass fraction and the assumptions made about its size distribution, amongst many other aerosol processes. We do not test the sensitivity of our results to the assumptions made about the sub-grid sulphate fraction because we expect the uncertainty in the volcanic sulphur source strength to have a much larger impact on our results.

Andres and Kasgnoc (1998) noted that their inventory is likely an underestimate as only 74 volcanoes are considered (i.e. the ones that featured flux measurements). For comparison, the Smithsonian's Global Volcanism Program (http:// www.volcano.si.edu/world/summary.xls) lists more than 200 subaerial volcanoes that erupted during the 20th century - a criterion that could be used to declare a volcano as active. Textor et al. (2004) noted that difficulties in extrapolation to account for unmonitored volcanoes lead to an uncertainty in the estimated magnitude of the global volcanic sulphur flux. Pfeffer et al. (2006) also noted that global volcanic emission inventories extrapolated from measurements at individual volcanoes are likely to underestimate the total volcanic sulphur flux. In addition, although the volcanic sulphur flux strength has been estimated for PD conditions, the emissions at individual volcanoes are often highly variable (e.g., Oppenheimer et al., 2011), and could have been higher or lower in the PI era. Based on previous estimates of the volcanic flux strength (Graf et al., 1997, 1998; Halmer et al., 2002; see also review by Textor et al., 2004, Table 2) it seems reasonable to halve and double the Andres and Kasgnoc (1998) inventory for the purpose of a sensitivity study. Graf et al. (1997) provided a detailed assessment of the global volcanic sulphur flux strength and its uncertainty range and estimated a flux range of $14 \pm 6 \operatorname{Tg}(\mathrm{S}) \mathrm{a}^{-1}$, which is close to what we consider to be plausible upper and lower limits of the volcanic flux strength used in our study. For a comprehensive review of "volcanism in space and time" see also Simkin (1993).

\subsection{Treatment of aerosol activation and model evaluation}

Cloud condensation nuclei are a subset of the entire aerosol population that would nucleate to cloud droplets at a given supersaturation. Several observations at continuously degassing volcanoes have shown that volcanic aerosol particles act as CCN in the troposphere (e.g., Mather et al., 2003a, b, 2004; Mather, 2008). However, the global impact of volcanic degassing on $\mathrm{CCN}$ has not been quantified (Oppenheimer et al., 2011).

In our study, $\mathrm{CCN}$ are counted as hygroscopic particles with a dry radius larger than $35 \mathrm{~nm}$, which is equivalent to particles that would activate into cloud droplets at $0.22 \%$ supersaturation (assuming sulphate composition). A change in CCN number concentrations at low- and mid-level cloud altitude can subsequently cause a cloud-radiative effect via the change in CDNC. As this study uses a 3-D offline chemical transport model, we do not account for feedbacks between the additional aerosol loading and atmospheric dynamics. Nober et al. (2003) showed that such feedbacks are potentially important, however the aim of our study is to quantify first-order effects of volcanic degassing on global CDNC. 

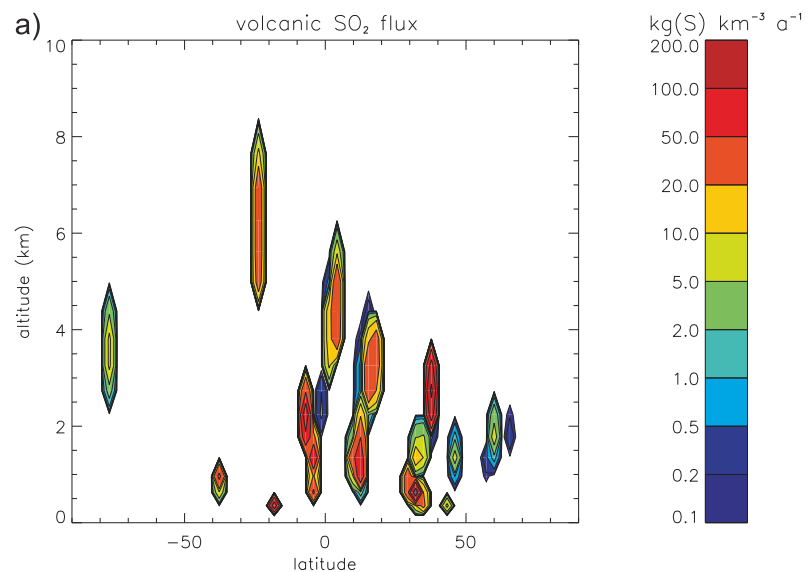

b)

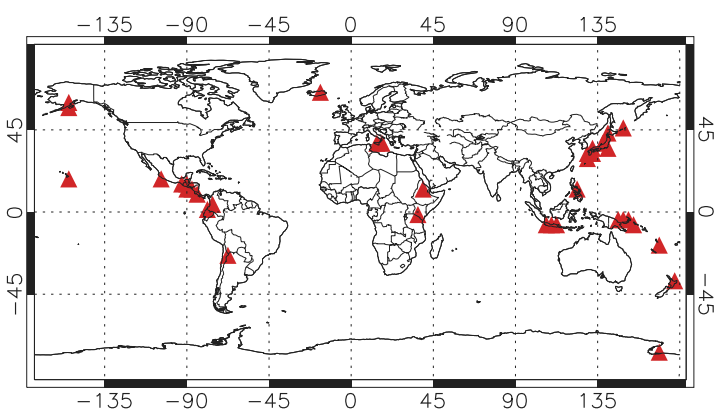

Fig. 2. Representation of the volcanic sulphur flux in GLOMAP-mode with (a) annual zonal mean volcanic $\mathrm{SO}_{2}$ flux $\left(\mathrm{kg}(\mathrm{S}) \mathrm{km}^{-3} \mathrm{a}^{-1}\right)$ using the Andres and Kasgnoc (1998) inventory, and (b) geographical location of the volcanic sources.

In GLOMAP, CDNC is calculated in a post-processing step using a physically-based aerosol activation scheme (Nenes and Seinfeld, 2003; Barahona et al., 2010) as evaluated and described by Pringle et al. (2009). This off-line CDNC approach is based on monthly mean size distributions using an updraught velocity of $0.3 \mathrm{~m} \mathrm{~s}^{-1}$ over land areas and of $0.15 \mathrm{~m} \mathrm{~s}^{-1}$ over the oceans. Updraught velocities of $0.1-$ $0.3 \mathrm{~m} \mathrm{~s}^{-1}$ are most commonly observed in stratus clouds (e.g., Gultepe and Isaac, 1999; Peng et al., 2005). Note that deriving monthly-mean CDNC from monthly-mean sizeresolved particle concentrations and monthly-mean particle composition fields does not account for temporal variations in aerosol properties. However, our approach and our choice of updraught velocities have been shown to provide a good approximation of mean CDNC (Fountoukis et al., 2007; Pringle et al., 2009; Karydis et al., 2011). As with many other aerosol activation schemes (e.g., Chen and Penner, 2005; Roelofs et al., 2006), the employed scheme does not account for droplet collision-coalescence (i.e. no droplet loss rate), thus CDNCs are shown at cloud-base altitude.

In Fig. 3 we show the evaluation of the ability of GLOMAP-mode to simulate CCN number concentrations.
Such an evaluation is important because the sensitivity of $\mathrm{CCN}$ number concentrations and $\mathrm{CDNC}$ to changes in the volcanic sulphur flux is strongly dependent on background CCN (CDNC). In general, the higher background $\mathrm{CCN}$ (CDNC) are, the lower the relative change in CCN (CDNC) for the same change in e.g., volcanic sulphur flux (Lohmann and Feichter, 2005). To evaluate the model's skill we use the CCN observations compiled by Spracklen et al. (2011) and apply the same methodology as described there. Briefly, we compare modelled and observed CCN concentrations by accounting for both the month and the supersaturation of each measurement. Figure 3 a shows that under PD conditions the model shows reasonable agreement with the observations (Pearson's correlation $r=0.60$ and a normalised mean bias (NMB) of $-38.2 \%$ ). By using $\mathrm{CCN}$ observations made in the marine boundary layer only (Fig. 3b), we test the model's skill in predicting $\mathrm{CCN}$ under relatively clean atmospheric conditions, and found good agreement with $r=0.45$ and a NMB of $24.2 \%$.

\subsection{Model experiments}

We conduct two sets of model runs:

1. With and without volcanic emissions for PI and PD atmospheric conditions. The volcanic emissions are as defined in the Andres and Kasgnoc (1998) inventory but following the recommendations of Dentener et al. (2006). We refer to these runs as PI_vol, PI_no_vol, PD_vol, and PD_no_vol. The other emission inventories used for these runs are described in Sect. 2.1. These runs enable us to quantify the contribution of volcanic degassing to the PI and PD cloud albedo effect.

2. Sensitivity runs in which the Andres and Kasgnoc inventory is halved and doubled. We refer to these runs as PI_vol $\times 0.5$, PI_vol $\times 2.0$, PD_vol $\times 0.5$, and PD_vol $\times 2.0$.

The paired runs PI_vol \& PD_vol, PI_vol $\times 0.5 \&$ PD_vol $\times 0.5$, and PI_vol $\times 2.0$ \& PD_vol $\times 2.0$ allow the anthropogenic cloud albedo radiative forcing to be calculated under the assumption that the volcanic emissions did not change between PI and PD. Other combinations of paired runs such as PI_vol $\times 0.5 \&$ PD_vol $\times 2.0$ provide an estimate of the total cloud albedo radiative forcing of changing anthropogenic and volcanic emissions. Note that the assessment of the PI aerosol-cloud state is of specific interest because it constitutes the baseline upon which the magnitude of the cloud albedo forcing due to anthropogenic aerosol is calculated (following the method used by the IPCC, see Forster et al., 2007).

\subsection{Radiative transfer code}

The cloud albedo effect is calculated with the off-line version of the Edwards and Slingo (1996) radiative transfer model. 

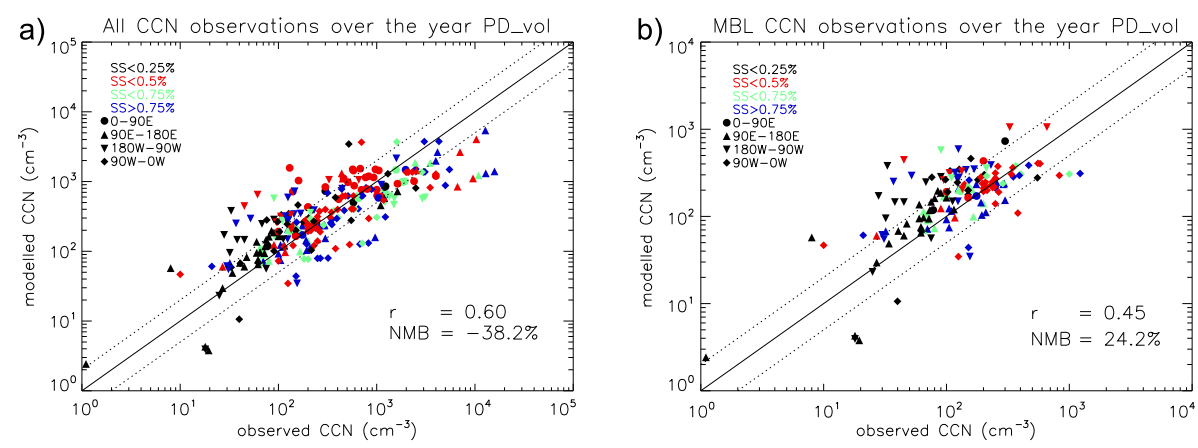

Fig. 3. Observed versus modelled cloud condensation nuclei $(\mathrm{CCN})$ number concentrations with (a) model evaluation using the present-day (PD) simulation including volcanic emissions against all CCN observations over the year; and (b) evaluation of the PD simulation that includes volcanic emissions against marine boundary layer (MBL) CCN observations only. The solid line represents the 1:1 relationship and the dotted lines show the 1:2 and 2:1 relationships. The colours indicate the supersaturation and the symbols indicate the region of the modelled/observed CCN as shown in the plots' keys. The Pearson's correlation coefficient is stated as $r$, and the normalised mean bias $(\mathrm{NMB}$, in $\%)$ is calculated as follows: $\mathrm{NMB}=100 \% \times \sum\left(M_{i}-O_{i}\right) / \sum O_{i}$ where $M_{i}$ refers to the modelled CCN concentration and $O_{i}$ to the observed $\mathrm{CCN}$ concentration. For the comparison both the month and the supersaturation of each CCN measurement was taken into account using the method and observational CCN dataset described and compiled by Spracklen et al. (2011).

A monthly-mean climatology, with a 144 (longitude) $\times 72$ (latitude) $\times 23$ (altitude) resolution for water vapour, temperature and $\mathrm{O}_{3}$ data (based on ECMWF reanalysis) together with surface albedo and low-, middle- and high-cloud fields (averaged over the period 1983-2005) from the International Satellite Cloud Climatology (ISCCP) is employed (for details see Rap et al., 2010; Spracklen et al., 2011). The cloud albedo effect between a control and a perturbed experiment is quantified by modifying the cloud droplet effective radius $r_{\mathrm{e}}$ (in $\mu \mathrm{m}$ ), for low- and mid-level water clouds (up to $600 \mathrm{hPa}$ ) only, as follows:

$r_{\mathrm{e}}^{\text {perturbed }}=r_{\mathrm{e}}^{\text {control }} \times\left(\mathrm{CDNC}^{\text {control }} / \mathrm{CDNC}^{\text {perturbed }}\right)^{1 / 3}$

where CDNC (in $\mathrm{cm}^{-3}$ ) corresponds to the monthly-mean cloud droplet number concentration calculated from a particular GLOMAP-mode simulation, and a fixed value for $r_{\mathrm{e}}^{\text {control }}=10 \mu \mathrm{m}$ is considered in order to ensure consistency with the ISCCP cloud retrievals. For example, when calculating the volcanically induced cloud albedo effect for PD atmospheric conditions, CDNC ${ }^{\text {control }}$ corresponds to PD_vol and $\mathrm{CDNC}^{\text {perturbed }}$ corresponds to PD_no_vol. When calculating the anthropogenic cloud albedo forcing between PI and PD, $\mathrm{CDNC}^{\text {control }}$ corresponds to PD_vol and $\mathrm{CDNC}^{\text {perturbed }}$ corresponds to PI_vol.

\section{Results}

\subsection{Contribution of volcanic degassing to cloud condensation nuclei}

Table 1 provides an overview of the global, hemispheric and regional annual mean PI and PD CCN number concentrations at cloud-base altitude $(\sim 1 \mathrm{~km})$ for the simulations with and without volcanic emissions. Additionally,
Fig. A1 (Appendix) shows the spatial distribution of the annual mean $\mathrm{CCN}$ concentrations. Without volcanic emissions, GLOMAP-mode simulates global annual mean CCN concentrations at cloud-base of $96 \mathrm{~cm}^{-3}$ for PI and $237 \mathrm{~cm}^{-3}$ for PD. Including volcanic emissions increases global annual mean CCN number concentrations by $\sim 43 \%$ for PI and by $\sim 12 \%$ for PD (i.e. to $\sim 137 \mathrm{~cm}^{-3}$ and to $\sim 264 \mathrm{~cm}^{-3}$, respectively). In other words, at cloud-base, volcanic emissions contribute $\sim 30 \%$ to PI global annual mean $\mathrm{CCN}$, whereas they contribute only $\sim 10 \%$ in the PD.

The uncertainty range in $\mathrm{CCN}$ caused by the $-50 \% /+100 \%$ uncertainty in the volcanic flux strength is also given in Table 1. The relative changes in $\mathrm{CCN}$ concentrations are non-linear: the greater the change in volcanic sulphur flux, the less effectively these emissions contribute to global CCN. For example, doubling the emissions increases global annual mean $\mathrm{CCN}$ concentrations by $\sim 66 \%$ for PI and $\sim 18 \%$ for PD (i.e. to $\sim 159 \mathrm{~cm}^{-3}$ and to $\sim 280 \mathrm{~cm}^{-3}$, respectively) when compared to the simulations without volcanic emissions. Our findings are reinforced by Gunson et al. (2006) who also found a non-linear response of the aerosol-cloud-climate system for halving and doubling DMS emissions under PD conditions.

To help understand what drives this non-linear CCN sensitivity to volcanic $\mathrm{SO}_{2}$ emissions, we analyse diagnostics for the sulphur fluxes through the chemical and microphysical processes (Table 2). The global annual mean sulphur budgets reveal that aqueous-phase oxidation of $\mathrm{SO}_{2}$ dominates over the gas-phase oxidation of $\mathrm{SO}_{2}$ by a factor of 9.0 for PI and a factor of 4.3 for PD conditions when excluding volcanic emissions, and by factors of 4.4 (PI) and 3.8 (PD) when including volcanic emissions. In contrast, a $100 \%$ increase in the sulphur flux from volcanoes results in the gasphase oxidation of $\mathrm{SO}_{2}$ becoming more important relative to 
Table 1. Annual mean cloud concentration nuclei $(\mathrm{CCN})$ number concentrations at low-level cloud altitude (approx. $970 \mathrm{~m}$ above terrain or sea level) for pre-industrial (PI) and present-day (PD). The relative increases and the relative contributions always refer to the run without volcanic emissions (i.e. no_vol). Here, $\mathrm{CCN}$ is counted as soluble particles with a dry radius larger than $35 \mathrm{~nm}$, which is equivalent to the particles that would activate into cloud droplets at $0.22 \%$ supersaturation (assuming sulphate composition).

\begin{tabular}{lccccccc}
\hline $\begin{array}{l}\mathrm{CCN}(r>35 \mathrm{~nm}) \\
\left(\mathrm{cm}^{-3}\right)\end{array}$ & no_vol & vol & $\begin{array}{c}\text { \%increase } \\
\text { [\%contrib.] }\end{array}$ & vol $\times 0.5$ & $\begin{array}{c}\text { \%increase } \\
\text { [\%contrib.] }\end{array}$ & vol $\times 2.0$ & $\begin{array}{c}\text { \%increase } \\
{[\% \text { contrib.] }}\end{array}$ \\
\hline pre-industrial (PI) & & & & & & & \\
\hline global mean & 96.1 & 137.2 & $42.7[29.9]$ & 122.6 & $27.5[21.6]$ & 159.4 & $65.8[39.7]$ \\
NH mean & 92.9 & 132.8 & $42.9[30.0]$ & 116.1 & $24.9[19.9]$ & 158.9 & $71.0[41.5]$ \\
SH mean & 99.4 & 141.6 & $42.5[29.8]$ & 129.1 & $29.9[23.0]$ & 160.0 & $60.9[37.9]$ \\
tropics mean [21 $\left.{ }^{\circ} \mathrm{N}-21^{\circ} \mathrm{S}\right]$ & 140.1 & 204.9 & $46.3[31.7]$ & 182.8 & $30.5[23.4]$ & 236.3 & $68.7[40.7]$ \\
\hline present-day (PD) & & & & & & & \\
\hline global mean & 236.6 & 263.8 & $11.5[10.3]$ & 253.5 & $7.1[6.7]$ & 280.1 & $18.4[15.5]$ \\
NH mean & 314.2 & 337.1 & $7.3[6.8]$ & 327.2 & $4.1[4.0]$ & 354.2 & $12.7[11.3]$ \\
SH mean & 158.3 & 189.9 & $20.0[16.7]$ & 179.1 & $13.2[11.7]$ & 205.4 & $29.8[22.9]$ \\
tropics mean [21 $\left.{ }^{\circ} \mathrm{N}-21^{\circ} \mathrm{S}\right]$ & 290.0 & 336.3 & $16.0[13.8]$ & 319.5 & $10.2[9.3]$ & 361.2 & $24.6[19.7]$ \\
\hline
\end{tabular}

the aqueous-phase oxidation of $\mathrm{SO}_{2}$ (i.e. factors of $3.0(\mathrm{PI})$ and 3.3 (PD) between aqueous-phase and gas-phase oxidation). Most of the volcanic sulphur is emitted well above the boundary layer into the free troposphere (Fig. 2) where $\mathrm{OH}$ is the dominant oxidant, thus explaining the shift towards gas-phase oxidation. The stronger gas-phase oxidation of $\mathrm{SO}_{2}$ produces more $\mathrm{H}_{2} \mathrm{SO}_{4}$ vapour which subsequently increases nucleation of new particles. The more numerous small particles which result compete with each other and with pre-existing aerosol for the available $\mathrm{H}_{2} \mathrm{SO}_{4}$ vapour. As a result, in relative terms, fewer particles grow to $\mathrm{CCN}$ sizes for a doubling of the volcanic sulphur flux, hence explaining the non-linear increase in CCN (Table 1). Thus, key processes governing the production of additional climaterelevant $\mathrm{CCN}$-sized particles from volcanic degassing are nucleation and condensation, which in turn are driven by the relative balance of gas-phase oxidation to aqueous-phase oxidation of $\mathrm{SO}_{2}$. The results demonstrate that the balance between these chemical and microphysical processes shifts even under modest perturbations to the magnitude of the volcanic sulphur flux.

\subsection{Contribution of volcanic degassing to cloud droplet number}

Given the substantial contribution of tropospheric volcanic aerosol to global CCN number concentrations, we next assess its impact on CDNC using a physically-based aerosol activation scheme (Nenes and Seinfeld, 2003; Barahona et al., 2010).

Figure 4 shows the impact of volcanic degassing on zonal mean CDNC at cloud-base altitude for PI (solid blue line) and PD (solid grey line). The blue and grey shading shows the impact of the $-50 \% /+100 \%$ uncertainty in the volcanic sulphur source strength. Under PD conditions, simu- lated zonal mean CDNC peaks at $\sim 304 \mathrm{~cm}^{-3}$ at $30^{\circ} \mathrm{N}$ when including volcanic emissions; an increase of $\sim 5 \%$ compared to the PD_no_vol simulation. In contrast, for PI conditions zonal mean CDNC peaks at $\sim 159 \mathrm{~cm}^{-3}$ at $15^{\circ} \mathrm{S}$; an increase of $\sim 40 \%$ compared to the PI_no_vol simulation. Thus, volcanic degassing causes a greater relative change in CDNC during PI atmospheric conditions compared to PD conditions. This PI to PD difference is particularly apparent in the latitude band $10^{\circ} \mathrm{N}-30^{\circ} \mathrm{N}$, where anthropogenic emissions substantially increase background CDNC in the PD_no_vol simulation. When accounting for the $-50 \% /+100 \%$ uncertainty, PI CDNC increases by $32-80 \%$ in this latitude band, but only by $5-13 \%$ for PD conditions when compared to the respective PI and PD no_vol simulations.

The impact of volcanic degassing on global and hemispheric annual mean CDNC is shown in Table 3. Under PI conditions, global mean CDNC is $\sim 76 \mathrm{~cm}^{-3}$ without volcanic emissions and $\sim 107 \mathrm{~cm}^{-3}$ when including volcanic emissions; an increase of $\sim 40 \%$. By contrast, under PD conditions, global mean CDNC rises from $\sim 158 \mathrm{~cm}^{-3}$ in the PD_no_vol simulation to $\sim 174 \mathrm{~cm}^{-3}$ in the PD_vol simulation; an increase of only $\sim 10 \%$. Thus, globally averaged, volcanic emissions cause a four times larger percentage increase in CDNC in the PI era compared to PD. This finding has implications for the aerosol indirect effects on climate induced by volcanic degassing in the PI and the PD era because as illustrated in Fig. 5a, it is the relative change in CDNC that governs the magnitude of the cloud albedo effect.

The spatial distribution of CDNC for the runs with and without volcanic emissions are shown in Fig. 6. The absolute changes shown in Fig. 6e, f highlight that volcanic sulphur emissions play an important role in modulating cloud microphysical properties in regions with persistent stratocumulus cloud decks as well as in those with trade cumulus cloud 
Table 2. Simulated global annual mean sulphur budget showing fluxes $\left(\operatorname{Tg}(\mathrm{S}) \mathrm{a}^{-1}\right)$, burdens in $\operatorname{Tg}(\mathrm{S})$ and lifetimes (days). ST2003a refers to Stevenson et al. (2003a) with values in parentheses denoting their estimate of the volcanic contribution, and ST2003b refers to the 1860 simulation in Stevenson et al. (2003b). Note, for our study the $\mathrm{SO}_{2}$ fluxes from different sources are given following the partitioning into $\mathrm{SO}_{2}$ and sub-grid sulphate (see Sect. 2.2 for details).

\begin{tabular}{|c|c|c|c|c|c|}
\hline & PD_no_vol & PD_vol & $\begin{array}{c}\text { ST2003a } \\
\text { [volcanic } \\
\text { contribution] }\end{array}$ & PD_vol $\times 0.5$ & PD_vol $\times 2.0$ \\
\hline $\mathrm{SO}_{2}$ flux (volcanic) & 0 & 12.28 & 9.00 & 6.14 & 24.57 \\
\hline $\mathrm{SO}_{2}$ flux (anthropogenic) & 52.85 & 52.85 & 71 & 52.85 & 52.85 \\
\hline $\mathrm{SO}_{2}$ flux (biomass burning) & 1.37 & 1.37 & 1.4 & 1.37 & 1.37 \\
\hline $\mathrm{DMS}(\mathrm{O})$ to $\mathrm{SO}_{2}$ & 17.09 & 17.09 & 12 & 17.09 & 17.09 \\
\hline $\mathrm{SO}_{2}$ burden $(\operatorname{Tg}(\mathrm{S}))$ & 0.22 & 0.32 & $0.29[0.075]$ & 0.27 & 0.42 \\
\hline $\mathrm{SO}_{2}$ dry deposition & 25.13 & 26.87 & $30[0.75]$ & 25.89 & 29.16 \\
\hline $\mathrm{SO}_{2}$ wet deposition & 4.67 & 7.64 & $9.2[1.4]$ & 6.01 & 11.22 \\
\hline $\mathrm{SO}_{2}$ lifetime (days) & 1.13 & 1.37 & $1.1[3.0]$ & 1.25 & 1.59 \\
\hline gas-phase ox. of $\mathrm{SO}_{2}($ by $\mathrm{OH})$ & 7.96 & 10.40 & $6.3[1.0]$ & 9.10 & 13.19 \\
\hline aq. phase $\mathrm{SO}_{2}$ ox. (by $\mathrm{O}_{3}$ and $\mathrm{H}_{2} \mathrm{O}_{2}$ ) & 34.23 & 39.34 & $49[5.85]$ & 37.11 & 42.97 \\
\hline $\mathrm{H}_{2} \mathrm{SO}_{4}-\mathrm{H}_{2} \mathrm{O}$ nucleation & 0.008 & 0.013 & - & 0.010 & 0.018 \\
\hline condensation (all modes) & 7.92 & 10.36 & - & 9.06 & 13.14 \\
\hline coagulation (all modes) & 0.30 & 0.45 & - & 0.38 & 0.59 \\
\hline $\mathrm{SO}_{4}$ burden $(\mathrm{Tg}(\mathrm{S}))$ & 0.47 & 0.59 & $0.81[0.12]$ & 0.53 & 0.69 \\
\hline $\mathrm{SO}_{4}$ dry deposition & 5.74 & 6.67 & $7.1[0.56]$ & 6.24 & 7.44 \\
\hline $\mathrm{SO}_{4}$ wet deposition & 37.81 & 44.75 & $49[6.2]$ & 41.49 & 50.71 \\
\hline \multirow[t]{2}{*}{$\mathrm{SO}_{4}$ lifetime (days) } & 3.91 & 4.17 & $5.3[6.2]$ & 4.05 & 4.34 \\
\hline & PI_no_vol & PI_vol & ST2003b & PI_vol $\times 0.5$ & PI_vol $\times 2.0$ \\
\hline $\mathrm{SO}_{2}$ flux (volcanic) & 0.00 & 12.28 & 8.80 & 6.14 & 24.57 \\
\hline $\mathrm{SO}_{2}$ flux (anthropogenic) & 0 & 0 & 0 & 0 & 0 \\
\hline $\mathrm{SO}_{2}$ flux (biomass burning) & 0.71 & 0.71 & 0.28 & 0.71 & 0.71 \\
\hline $\mathrm{DMS}(\mathrm{O})$ to $\mathrm{SO}_{2}$ & 17.07 & 17.07 & 12.2 & 17.07 & 17.07 \\
\hline $\mathrm{SO}_{2}$ burden $(\mathrm{Tg}(\mathrm{S}))$ & 0.04 & 0.13 & 0.09 & 0.08 & 0.23 \\
\hline $\mathrm{SO}_{2}$ dry deposition & 2.80 & 4.15 & 1.80 & 3.40 & 6.36 \\
\hline $\mathrm{SO}_{2}$ wet deposition & 1.24 & 4.01 & 2.20 & 2.49 & 7.48 \\
\hline $\mathrm{SO}_{2}$ lifetime (days) & 0.90 & 1.54 & 1.60 & 1.26 & 1.94 \\
\hline gas-phase ox. of $\mathrm{SO}_{2}($ by $\mathrm{OH})$ & 1.39 & 3.99 & 1.90 & 2.62 & 7.15 \\
\hline aq. phase $\mathrm{SO}_{2}$ ox. (by $\mathrm{O}_{3}$ and $\mathrm{H}_{2} \mathrm{O}_{2}$ ) & 12.46 & 17.60 & 15.40 & 15.50 & 21.43 \\
\hline $\mathrm{H}_{2} \mathrm{SO}_{4}-\mathrm{H}_{2} \mathrm{O}$ nucleation & 0.004 & 0.008 & - & 0.006 & 0.013 \\
\hline condensation (all modes) & 1.37 & 3.97 & - & 2.60 & 7.12 \\
\hline coagulation (all modes) & 0.06 & 0.20 & - & 0.13 & 0.32 \\
\hline $\mathrm{SO}_{4}$ burden $(\mathrm{Tg}(\mathrm{S}))$ & 0.14 & 0.27 & 0.28 & 0.21 & 0.39 \\
\hline $\mathrm{SO}_{4}$ dry deposition & 1.97 & 2.97 & 1.50 & 2.54 & 3.84 \\
\hline $\mathrm{SO}_{4}$ wet deposition & 11.90 & 19.00 & 15.80 & 15.76 & 25.40 \\
\hline $\mathrm{SO}_{4}$ lifetime (days) & 3.64 & 4.47 & 5.80 & 4.17 & 4.82 \\
\hline
\end{tabular}

cover. For example, along the subtropical west coast of South America (area is indicated by the green boxes in Fig. 6e, f) we find annual mean absolute CDNC changes of $\sim 50 \mathrm{~cm}^{-3}$ in the PI, and of $\sim 35 \mathrm{~cm}^{-3}$ in the PD, corresponding to mean relative increases of $\sim 51 \%$ and $\sim 29 \%$, respectively.

\subsection{Contribution of volcanic degassing to the cloud albedo effect}

Given that low-level clouds play a major role in the modulation of the Earth's radiation budget (e.g., Klein and Hartmann, 1993; Forster et al., 2007), we next assess the magnitude of the cloud albedo effect induced by volcanic 
Table 3. Annual mean cloud droplet number concentrations (CDNC) at cloud-base altitude (approx. $970 \mathrm{~m}$ above terrain or sea-level) for preindustrial (PI) and present-day (PD). The relative increases and the relative contributions always refer to the run without volcanic emissions (i.e. no_vol).

\begin{tabular}{lccccccc}
\hline $\begin{array}{l}\text { CDNC } \\
\left(\mathrm{cm}^{-3}\right)\end{array}$ & no_vol & vol & $\begin{array}{c}\text { \%increase } \\
{[\% \text { contrib.] }}\end{array}$ & vol $\times 0.5$ & $\begin{array}{c}\text { \%increase } \\
{[\% \text { contrib.] }}\end{array}$ & vol $\times 2.0$ & $\begin{array}{c}\text { \%increase } \\
{[\% \text { contrib.] }}\end{array}$ \\
\hline pre-industrial (PI) & & & & & & & \\
\hline global mean & 76.3 & 107.1 & $40.4[28.8]$ & 96.1 & $26.0[20.6]$ & 123.1 & $61.3[38.0]$ \\
NH mean & 73.6 & 108.7 & $47.8[32.3]$ & 94.8 & $28.9[22.4]$ & 128.6 & $74.8[42.8]$ \\
SH mean & 79.1 & 105.5 & $33.4[25.1]$ & 97.4 & $23.2[18.8]$ & 117.5 & $48.6[32.7]$ \\
tropics mean $\left[21^{\circ} \mathrm{N}-21^{\circ} \mathrm{S}\right]$ & 101.2 & 144.6 & $42.9[30.0]$ & 129.7 & $28.2[22.0]$ & 165.4 & $63.4[38.8]$ \\
\hline present-day (PD) & & & & & & & \\
\hline global mean & 157.7 & 174.1 & $10.4[9.4]$ & 167.7 & $6.4[6.0]$ & 183.9 & $16.6[14.3]$ \\
NH mean & 207.3 & 221.9 & $7.1[6.6]$ & 215.7 & $4.1[3.9]$ & 231.7 & $11.8[10.5]$ \\
SH mean & 107.7 & 126.0 & $17.0[14.5]$ & 119.3 & $10.8[9.7]$ & 135.8 & $26.1[20.7]$ \\
tropics mean [21 $\left.{ }^{\circ} \mathrm{N}-21^{\circ} \mathrm{S}\right]$ & 176.1 & 203.4 & $15.5[13.4]$ & 193.0 & $9.6[8.8]$ & 218.5 & $24.1[19.4]$ \\
\hline
\end{tabular}

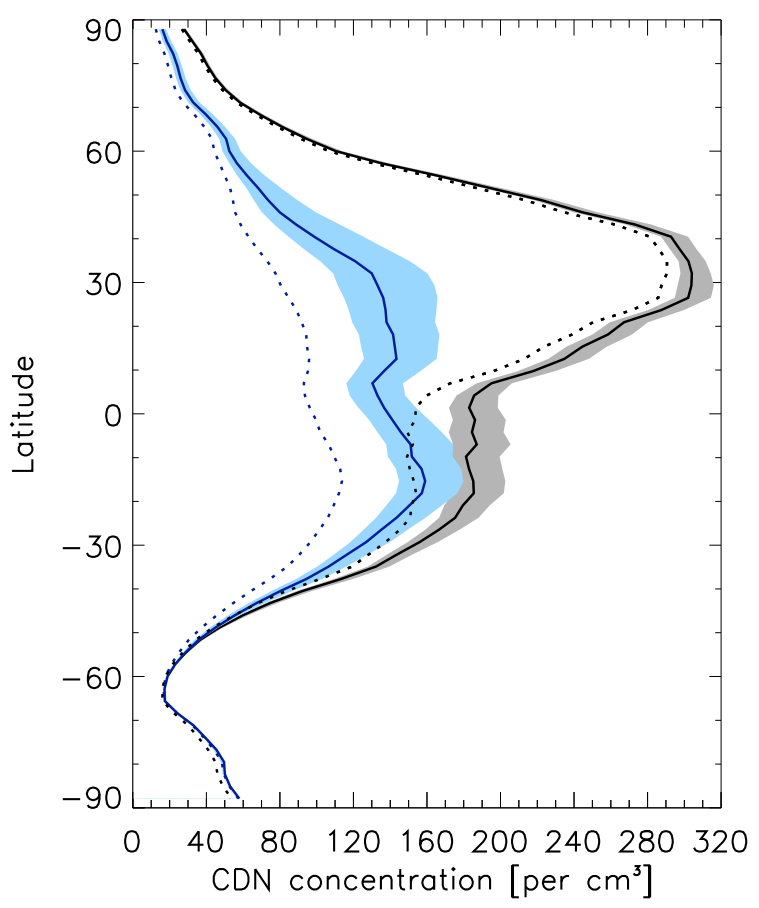

Fig. 4. Annual zonal mean cloud droplet number concentrations (CDNC) at cloud-base altitude (approx. $970 \mathrm{~m}$ above terrain or sea level) for the pre-industrial era (blue) and for present-day (grey). The dashed lines show the runs where volcanic emissions were omitted; the solid lines show the runs where the volcanic emissions inventory of Andres and Kasgnoc (1998) was used, and the blue and grey shading shows the impact of the $-50 \% /+100 \%$ uncertainty in the volcanic sulphur source strength on zonal mean CDNC.

degassing. To assess the net impact of volcanic degassing (i.e. combined longwave and shortwave effects) on the radiative balance at the top of the atmosphere the cloud albedo effect for low- and mid-level cloud changes (up to $600 \mathrm{hPa}$ ) is calculated and shown in Fig. 7. Additionally, Table 4 lists the hemispheric mean cloud albedo effects including their uncertainty ranges (that arise from halving and doubling the volcanic emission inventory) for PI and PD.

In the PI era, volcanic degassing induces a global annual mean cloud albedo effect of $-1.06 \mathrm{~W} \mathrm{~m}^{-2}$, whereas under PD conditions, we calculate a global annual mean cloud albedo effect of $-0.56 \mathrm{Wm}^{-2}$. This difference in the magnitude of the volcanically induced cloud albedo effect between PI and PD (that results even if one assumes a constant volcanic sulphur source strength) arises from differences in the baseline aerosol concentrations and from differences in the $\mathrm{CCN}$ formation processes as discussed in Sect. 3.1. Most simply, for the same absolute increase in volcanic aerosol loading, relative CDNC changes are less in the PD due to high background aerosol concentrations compared to the PI with lower background aerosol concentrations (Fig. 5a) (e.g., Lohmann and Feichter, 2005; Mahowald et al., 2011). However, absolute changes in global mean CDNC are also less in the PD $\left(174 \mathrm{~cm}^{-3}\right.$ versus $158 \mathrm{~cm}^{-3}$, difference $\left.16 \mathrm{~cm}^{-3}\right)$ compared to the PI $\left(107 \mathrm{~cm}^{-3}\right.$ versus $76 \mathrm{~cm}^{-3}$, difference $31 \mathrm{~cm}^{-3}$ ) as a result of non-linear interactions between chemical and microphysical processes, resulting in the production of more particles per unit of volcanic sulphur emission in the PI era (see Sect. 3.1 and Sect. 3.2). Ultimately, this PI to PD difference in the impact of volcanic degassing on CDNC results in a form of forcing that has to be accounted for in assessments of the anthropogenic aerosol indirect forcing of climate.

\subsection{Importance for aerosol indirect forcing of climate}

Intergovernmental Panel on Climate Change assessment reports (e.g., Forster et al., 2007) summarize estimates of the radiative forcing due to changes in aerosol since the PI era. Firstly, we provide an estimate of the magnitude of 


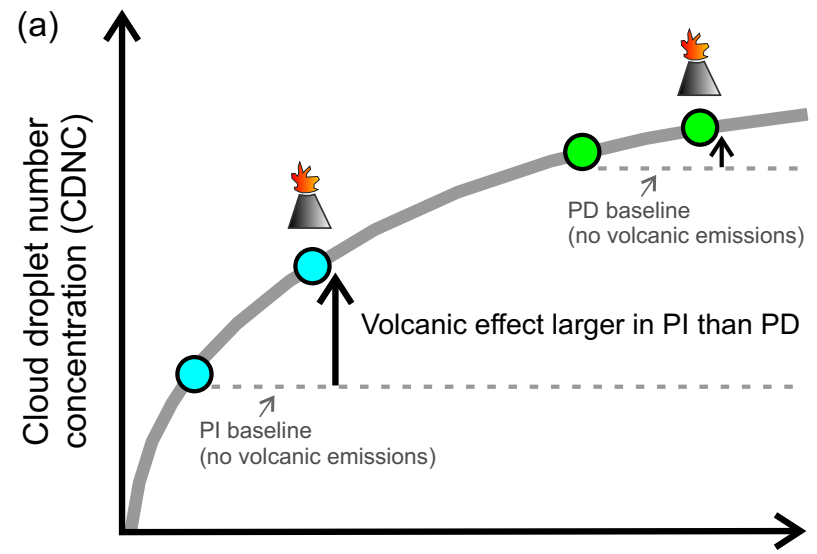

Aerosol number concentration

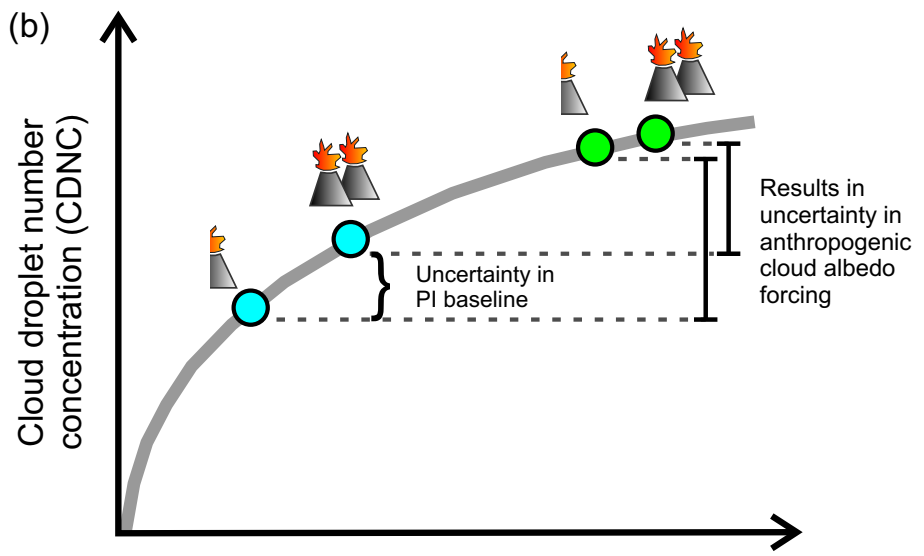

Aerosol number concentration

$$
\text { cloud albedo effect } \propto \frac{\triangle \mathrm{CDNC}}{\mathrm{CDNC} C^{\text {baseline }}}
$$

Fig. 5. Relationship between aerosol number concentration and cloud droplet number concentration (CDNC) with (a) showing that the volcanically induced cloud albedo effect is larger under pre-industrial (PI) atmospheric conditions (blue circles) than under present-day (PD) conditions (green circles) because of the greater relative change in $\mathrm{CDNC}\left(\triangle \mathrm{CDNC} / \mathrm{CDNC}{ }^{\text {baseline }}{\text { with } \triangle \mathrm{CDNC}=\mathrm{CDNC}{ }^{\mathrm{with}}-\text { volcanics }}_{-}\right.$ $\mathrm{CDNC}^{\text {baseline }}$ ) under PI conditions; and (b) showing the effect of the uncertainty in the PI baseline, which arises from the $-50 \% /+100 \%$ uncertainty in the volcanic flux strength, on the magnitude of the anthropogenic cloud albedo forcing.

the anthropogenic cloud albedo radiative forcing under the assumption that the volcanic sulphur source strength did not change between PI and PD, but also taking into account the $-50 \% /+100 \%$ uncertainty range in the volcanic flux. Secondly, we also calculate the magnitude of the total cloud albedo radiative forcing (i.e. volcanic and anthropogenic) assuming that the volcanic sulphur source strength changed between PI and PD. There is no observational evidence for a temporal change in the volcanic sulphur source strength. However, we believe such a change cannot be discounted either given the large inter-annual variability in the emissions observed at some of the largest volcanic sulphur sources.

We calculate a global annual mean cloud albedo radiative forcing due to anthropogenic aerosol of $-1.08 \mathrm{Wm}^{-2}$ (Fig. 8, red symbols), which is well within the range of the IPCC estimate of -0.3 to $-1.8 \mathrm{~W} \mathrm{~m}^{-2}$ (Forster et al., 2007). Assuming the volcanic sulphur flux is only $50 \%$ of that in Andres and Kasgnoc (1998) (but constant over the PI-PD period) we calculate a higher anthropogenic radiative forcing of $-1.16 \mathrm{~W} \mathrm{~m}^{-2}$ primarily because aerosol concentrations in the PI baseline are lower (Sects. 3.1 and 3.2). Similarly, assuming the volcanic flux is double that reported in Andres and Kasgnoc (1998), the calculated radiative forcing is reduced to $-0.86 \mathrm{~W} \mathrm{~m}^{-2}$.

Assuming that the volcanic sulphur flux strength changed between PI and PD, the magnitude of the total cloud albedo radiative forcing (from changes in volcanic and anthropogenic emissions) is shown by the black symbols in Fig. 8 . Clearly, the highest total cloud albedo radiative forcing
Table 4. Annual mean cloud albedo effect at the top of the atmosphere for changes of low- and mid-level clouds (up to $600 \mathrm{hPa}$ ) induced by volcanic degassing (i.e. w.r.t. the runs without volcanic emissions) for pre-industrial (PI) and present-day (PD).

\begin{tabular}{lccc}
\hline cloud albedo effect $\left(\mathrm{W} \mathrm{m}^{-2}\right)$ & vol & vol $\times 0.5$ & vol $\times 2.0$ \\
\hline pre-industrial (PI) & & & \\
\hline global mean & -1.06 & -0.77 & -1.56 \\
NH mean & -0.92 & -0.57 & -1.31 \\
SH mean & -1.22 & -0.99 & -1.83 \\
tropics mean $\left[21^{\circ} \mathrm{N}-21^{\circ} \mathrm{S}\right]$ & -1.62 & -1.11 & -2.18 \\
maximum & -6.67 & -4.92 & -8.68 \\
\hline present-day (PD) & & & \\
\hline global mean & & & \\
NH mean & -0.56 & -0.36 & -0.83 \\
SH mean & -0.32 & -0.20 & -0.51 \\
tropics mean $\left[21^{\circ} \mathrm{N}-21^{\circ} \mathrm{S}\right]$ & -0.82 & -0.54 & -1.19 \\
maximum & -3.99 & -0.58 & -1.31 \\
& & -2.68 & -5.60 \\
\hline
\end{tabular}

$\left(-1.64 \mathrm{~W} \mathrm{~m}^{-2}\right)$ results under the assumption that during the PI, volcanic emissions were at a plausible lower limit and at a plausible upper limit during the $\mathrm{PD}$, and the lowest forcing $\left(-0.38 \mathrm{~W} \mathrm{~m}^{-2}\right)$ results when the opposite is the case. These are extreme end-members of many reasonable changes in the volcanic sulphur flux strength within what we consider plausible upper and lower limits of $-50 \% /+100 \%$. 
a) PI no volcanic emissions

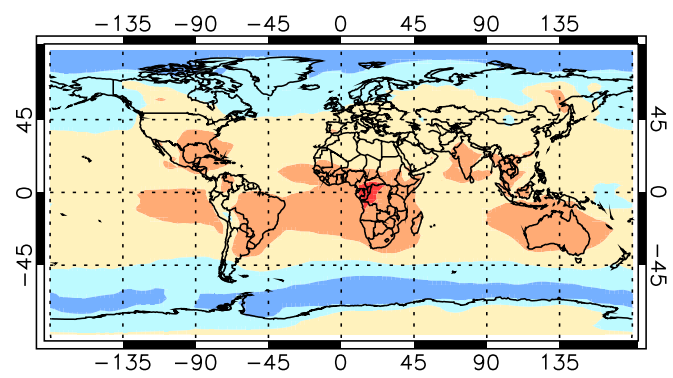

c) $\mathrm{Pl}$ incl. volcanic emissions
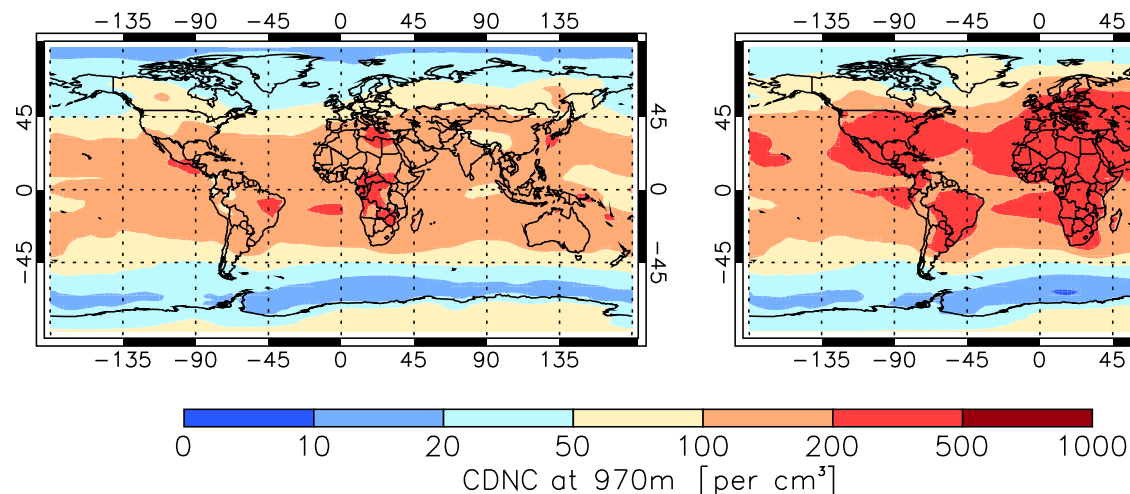

e) PI Change in CDNC (volcanics MINUS no volcanics)

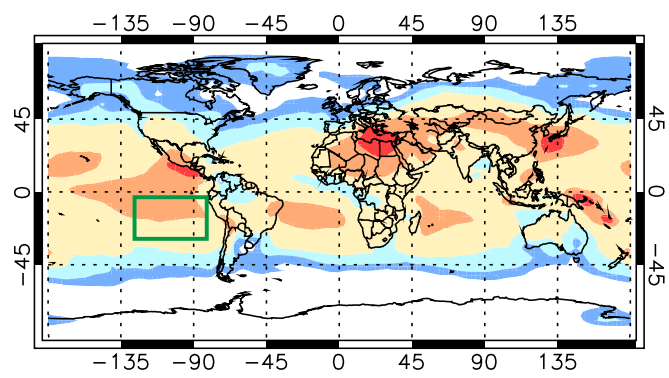

f) PD Change in CDNC (volcanics MINUS no volcanics)
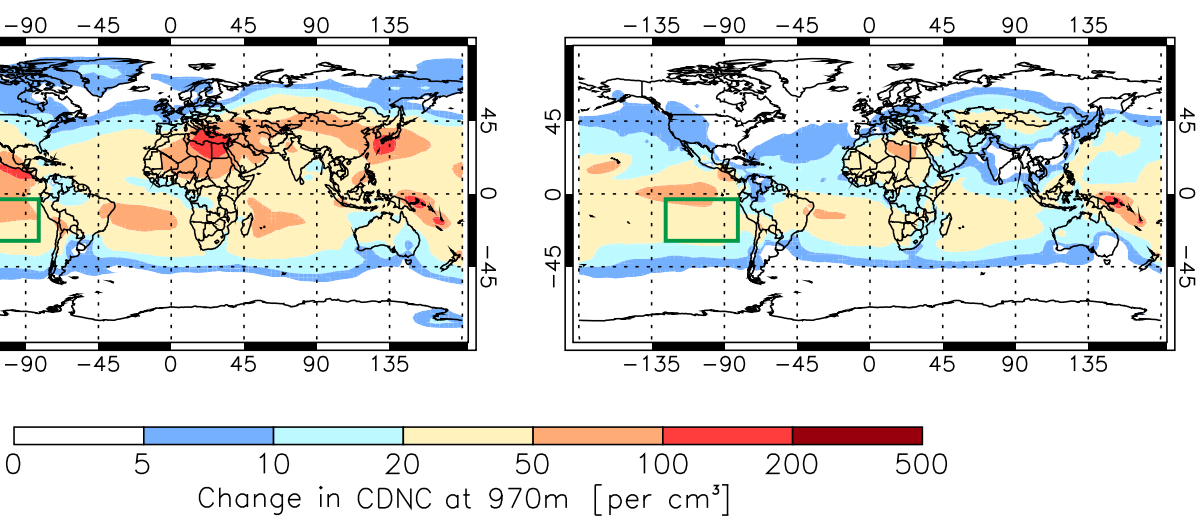

Fig. 6. Annual mean cloud droplet number concentrations $\left(\mathrm{CDNC}, \mathrm{cm}^{-3}\right)$ at cloud-base altitude (approx. $970 \mathrm{~m}$ above terrain or sea level) for (a) the pre-industrial (PI) era without volcanic emissions; (b) the present-day (PD) era without volcanic emissions; (c) PI era with volcanic emissions; and (d) PD era with volcanic emissions. The absolute difference in annual mean CDNC for the PI and PD eras are shown in panels (e) and (f), respectively. The green box to the west of South America covers the area between $82^{\circ} \mathrm{W}-132^{\circ} \mathrm{W}$ longitude and $4^{\circ} \mathrm{S}-29^{\circ} \mathrm{S}$ latitude (see Sect. 3.2).

\section{Discussion}

Here, we put our results in context with other natural sulphur sources such as DMS. Woodhouse et al. (2010) used the same global aerosol model and found that under PD conditions, DMS contributes $\sim 7 \%$ to global annual mean CCN number concentrations. Thus, taking into account the ratio of the global volcanic to DMS sulphur flux $\left(12.6 \mathrm{Tg}(\mathrm{S}) \mathrm{a}^{-1}\right.$ to $\left.17.1 \mathrm{Tg}(\mathrm{S}) \mathrm{a}^{-1}\right)$, volcanic emissions are nearly twice as effective as DMS emissions at contributing to global CCN concentrations under PD conditions. The less effective conversion of DMS to CCN is likely due to DMS-derived $\mathrm{SO}_{2}$ being produced in the marine boundary layer, where it is mostly oxidized in the aqueous phase resulting in growth of existing $\mathrm{CCN}$ without an increase in the number concentration of CCN-sized particles (Woodhouse et al., 2012). By 
a) PD net TOA cloud albedo effect. Global mean $=-0.56 \mathrm{~W} \mathrm{~m}^{-2}$

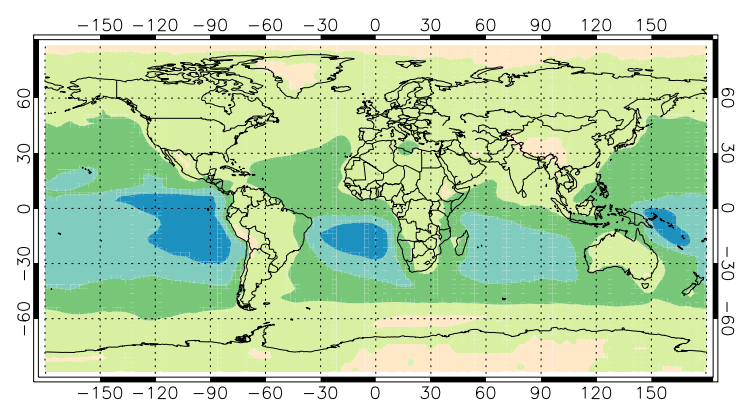

b) PI net TOA cloud albedo effect. Global mean=-1.06 $\mathrm{W} \mathrm{m}^{-2}$

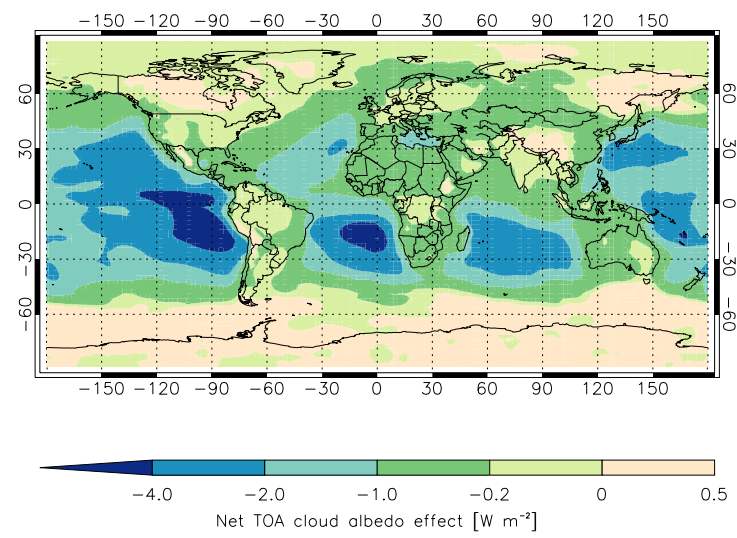

Fig. 7. Annual mean cloud albedo effect due to volcanic degassing using the Andres and Kasgnoc (1998) inventory in relation to the simulations where volcanic emissions were omitted. The cloud albedo effect is calculated at the top of the atmosphere (TOA) for low- and mid-level cloud changes (i.e. up to $600 \mathrm{hPa}$ ) for both preindustrial (PI) and present-day (PD) atmospheric conditions.

contrast, most volcanic $\mathrm{SO}_{2}$ is injected in the free troposphere, where oxidation is mostly in the gas-phase, leading to new $\mathrm{CCN}$ by enhanced nucleation and growth of Aitkensized particles.

Our results can also be put in context with other global aerosol modelling studies. Thomas et al. (2010) quantified DMS-induced changes in cloud microphysical properties and estimated a global annual mean total aerosol effect of $-2.03 \mathrm{~W} \mathrm{~m}^{-2}$ (i.e. direct + indirect effect) due to the presence of DMS emissions under PD atmospheric conditions (compared to our cloud albedo effect of $-0.56 \mathrm{~W} \mathrm{~m}^{-2}$ due to volcanic degassing). Graf et al. $(1997,1998)$ showed that different sulphur sources exert the strongest effects in different regions and different seasons (the latter has not been assessed in our study). For the volcanic source, we find a profound mean cloud albedo effect in the tropical zone $\left(-1.62 \mathrm{~W} \mathrm{~m}^{-2}\right.$ for PI and $-0.89 \mathrm{~W} \mathrm{~m}^{-2}$ for PD). Graf et al. (1997) found that under PD conditions, the annual mean cloud albedo effect due to DMS emissions exceeds $-3 \mathrm{Wm}^{-2}$ in several regions of the extra-tropical Southern Ocean where biological activity is most prevalent. In comparison, we cal- culate a maximum volcanically induced annual mean cloud albedo effect of $-6.67 \mathrm{Wm}^{-2}$ and $-3.99 \mathrm{Wm}^{-2}$ along the west coast of South America for PI and PD, respectively (Fig. 7). Comparing our results (Fig. 7) to those of Graf et al. (1997, Fig. 7), differences in the spatial pattern of the cloud albedo effect are apparent. We calculate a large cloud albedo effect over stratocumulus cloud regions whereas Graf et al. (1997) found a much reduced effect in those regions. These differences could be attributed to (i) the fact that observationally derived cloud fields from ISCCP (Rossow and Schiffer, 1999) have been used in our study whereas Graf et al. (1997) used cloud fields predicted by their climate model, and (ii) the fact that Graf et al. (1997) used an empirical relationship between sulphate aerosol mass and CDN (Boucher and Lohmann, 1995) whereas we use a physicallybased aerosol activation scheme (Nenes and Seinfeld, 2003; Barahona et al., 2010).

Yuan et al. (2011) used satellite retrievals to show that emissions from Kilauea's summit vent (Hawaii) induced a regional cloud albedo effect of up to $-4 \mathrm{Wm}^{-2}$. Using our global aerosol microphysics model, we calculate an annual mean cloud albedo effect around the Islands of Hawaii of $-2.32 \mathrm{~W} \mathrm{~m}^{-2}$ (uncertainty range -1.48 to $-3.17 \mathrm{~W} \mathrm{~m}^{-2}$ ) for $\mathrm{PI}$, and of $-1.07 \mathrm{~W} \mathrm{~m}^{-2}$ (uncertainty range $-0.64 \mathrm{~W} \mathrm{~m}^{-2}$ to $-1.68 \mathrm{~W} \mathrm{~m}^{-2}$ ) for PD. Note that our estimate of the radiative effects will be partly due to volcanic sulphur emissions from Hawaii and partly due to long-range transport of aerosol from other volcanoes. In the model, we emit a total of $\sim 2600 \mathrm{t}$ of $\mathrm{SO}_{2}$ per day in the gridboxes above Hawaii accounting for emissions from both the Kilauea's summit and east rift zone vents. Therefore, the comparison of our model estimate to the Yuan et al. (2011) study is for qualitative purposes only.

Boulon et al. (2011) suggested that using a binary homogeneous $\mathrm{H}_{2} \mathrm{SO}_{4}-\mathrm{H}_{2} \mathrm{O}$ nucleation scheme (Kulmala et al., 1998), as has been done in our study, will underestimate the climate impact induced by volcanic degassing because these authors observed very high nucleation rates in the boundary layer following the 2010 Eyjafjallajökull eruption. We carried out additional PD runs that included a widely used empirical approach to account for boundary layer nucleation (BLN) (e.g., Spracklen et al., 2006, 2010; Merikanto et al., 2010). We found that including BLN reduces the relative increase in CDNC due to volcanic degassing because baseline CDNC are higher than in the PD_no_vol run that neglected BLN. Consequently, we calculate a global annual mean cloud albedo effect that is $\sim 12 \%$ lower than that calculated for the PD runs without BLN, which is in contrast to what has been concluded by Boulon et al. (2011). Clearly, Boulon et al. (2011) made an important observation, however as long as we do not fully understand the precise nucleation mechanism operating, no conclusive statement can be made regarding the importance of BLN in affecting the magnitude of the climate impact of volcanic degassing. Several other studies also observed high sulphuric acid concentrations in the diluted Eyjafjallajökull volcanic plume (e.g., Schäfer et al., 


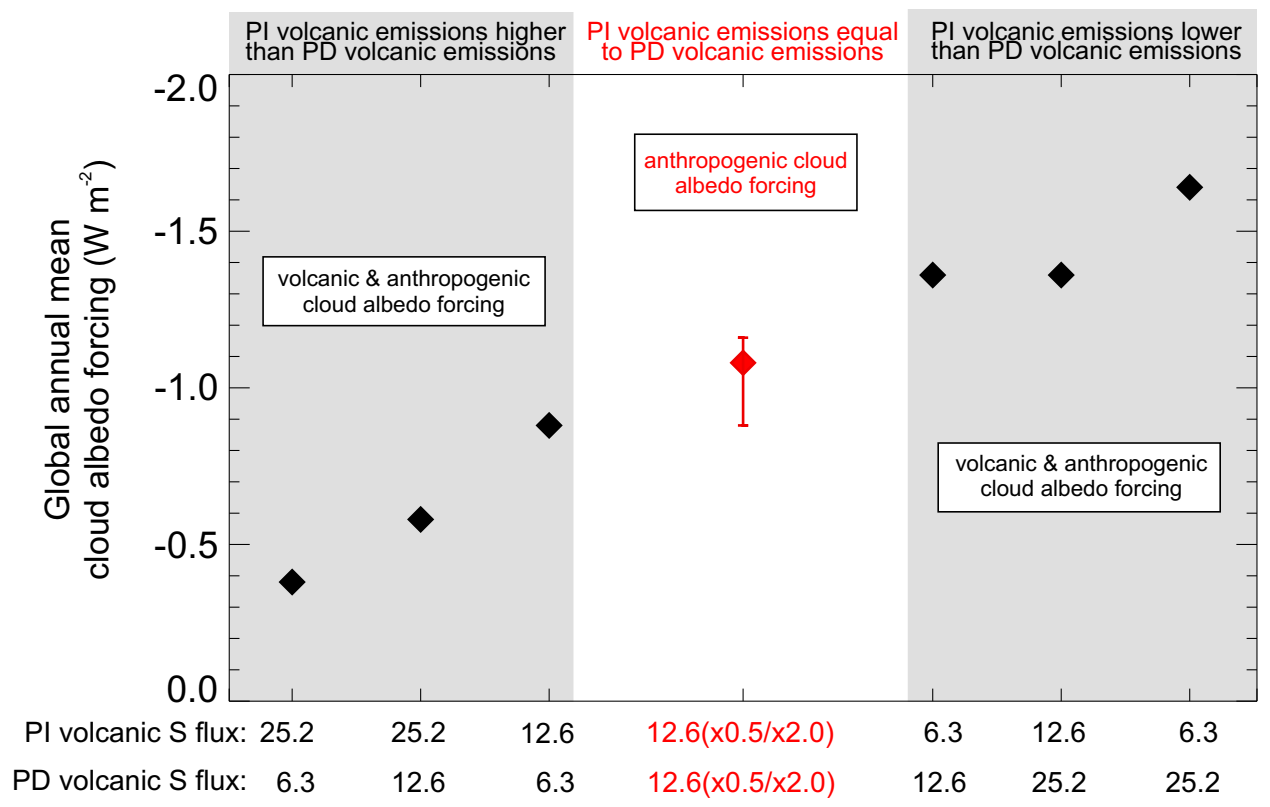

Fig. 8. Effect of the uncertainties in the volcanic sulphur source strength on the anthropogenic cloud albedo forcing. The red symbols show the magnitude and the uncertainty range of the anthropogenic cloud albedo forcing arising from the uncertainty in the volcanic source strength under the assumption that there was no change in the volcanic flux strength between the pre-industrial era (PI) and present-day (PD). The black symbols show the magnitude of the total cloud albedo forcing (i.e. volcanic and anthropogenic) that arise if one assumes differences in the volcanic sulphur flux strength between PI and PD. The x-axis shows the assumptions made about the strength of the volcanic sulphur flux (in $\operatorname{Tg}(\mathrm{S}) \mathrm{a}^{-1}$ ) for both PI and PD.

2011; Martucci et al., 2012). Therefore, it is also important to better understand and quantify aerosol microphysical processes including nucleation within volcanic plumes near the volcanic source and contrast these to processes that occur in the diluted volcanic plume and the rest of the atmosphere.

When averaged over the Northern Hemisphere, we find that the volcanically induced PD cloud albedo effect is only one-third of that in the PI era (Table 4). In other words, the "climate cooling potential" of tropospheric volcanic aerosol is effectively at least halved under PD conditions mainly due to the presence of anthropogenic aerosol pollution. Ward et al. (2012) found a similar 'masking' of the indirect aerosol effect induced by carbonaceous aerosol produced from fires between PI and PD. Given the high sensitivity of the relatively unpolluted PI atmosphere to volcanic emissions, implications arise for the assessment of the state of the climate system throughout Earth's history. For example, Kump and Pollard (2008) suggested that the mid-Cretaceous "greenhouse climate" could have been amplified by a diminished biogenic activity which subsequently led to a decrease in biogenically-derived $\mathrm{CCN}$ number concentrations, hence a lower cloud amount and albedo. However, volcanic activity varied in location and magnitude throughout Earth's history and potentially provided an important source of $\mathrm{CCN}-$ one of the many aerosol-cloud processes that remain to be included and investigated in palaeoclimate assessments.
Note that further uncertainties in the magnitude of the anthropogenic cloud albedo radiative forcing arise from uncertainties in the PI and PD baselines, which could originate from other poorly defined changes in natural emissions such as terpenes released from vegetation or from not accounting for certain sources such as fungal spores (Carslaw et al., 2010, and references therein).

\section{Conclusions}

We have used a global aerosol microphysics model to quantify the impact of continuously degassing and sporadically erupting volcanoes on global $\mathrm{CCN}$, global $\mathrm{CDNC}$, the radiative properties of low- and mid-level clouds and the cloud albedo radiative forcing between pre-industrial (PI) and present-day (PD). By halving and doubling the volcanic emission inventory (Andres and Kasgnoc, 1998) we aimed to provide an uncertainty assessment to draw attention to the importance of tropospheric volcanic aerosol in assessments of the aerosol indirect forcing of climate.

Our model simulations showed that tropospheric volcanic aerosol is an important natural contributor to climate-relevant $\mathrm{CCN}$-sized particles at cloud-base altitude on a global scale. We have shown that volcanic degassing can substantially alter the microphysical properties of low- and mid-level clouds and our results corroborate recent evidence of volcanically 


\begin{tabular}{|c|c|c|c|}
\hline $\begin{array}{c}\text { Volcanic } \\
\text { cloud albedo } \\
\text { effect }\end{array}$ & & $-0.56(-0.83$ to -0.36$)$ & Present-day \\
\hline $\begin{array}{c}\text { Anthropogenic } \\
\text { cloud albedo } \\
\text { forcing }\end{array}$ & $1.06(-1.56$ to -0.77$)$ & Pre-industrial \\
\hline $\begin{array}{c}\text { Anthropogenic } \\
\text { and volcanic } \\
\text { cloud albedo } \\
\text { forcing }\end{array}$ & $1-0.70(-1.80$ to -0.30$)$ & IPCC 2007 \\
\hline \\
\hline
\end{tabular}

Fig. 9. Summary of results showing the effect of uncertain volcanic sulphur emissions on the global annual mean cloud albedo effect induced by volcanic degassing and the anthropogenic cloud albedo forcing. The grey and blue bars show the magnitude and the uncertainty range for the volcanic cloud albedo effect for present-day (PD) and pre-industrial (PI), respectively. In the central panel, the top red bar shows the magnitude of the anthropogenic cloud albedo forcing as estimated by IPCC (Forster et al., 2007) based on a range of modelling studies using different aerosol species and mixtures. The red bar directly below it shows the magnitude of the anthropogenic cloud albedo forcing estimated in this study with the uncertainty range arising from the $-50 /+100 \%$ uncertainty in the volcanic source strength assuming the same volcanic flux strength over the PI-PD period. In the bottom panel, the dashed error bar shows the uncertainty range for the magnitude of the total cloud albedo forcing (i.e. combined volcanic and anthropogenic) assuming a change in the volcanic sulphur flux strength over the PI-PD period.

induced aerosol-cloud effects on regional scales deduced from satellite retrievals (Gassó, 2008; Yuan et al., 2011).

Globally averaged, volcanic emissions have about a four times larger percentage impact on cloud droplets in the PI era compared to PD (Table 3). Consequently, volcanic degassing induces a global annual mean cloud albedo effect of $-1.06 \mathrm{~W} \mathrm{~m}^{-2}$ under PI conditions but only $-0.56 \mathrm{~W} \mathrm{~m}^{-2}$ in the PD (Table 4; Fig. 9). This non-equal effect is explained partly by the lower background aerosol concentrations in the PI era, but also because more aerosol particles are produced per unit of volcanic sulphur emission in the PI atmosphere. Such findings have implications for the "climate cooling potential" of tropospheric volcanic aerosol during the past, the present and in future with the induced cloud albedo effect in the polluted PD Northern Hemisphere being diminished by anthropogenic activities to only one-third of that in the PI era (Table 4).

The higher sensitivity of the PI atmosphere to volcanic emissions has an important consequence for the anthropogenic cloud radiative forcing because the large uncertainty in volcanic emissions translates into an uncertainty in the PI baseline cloud radiative state from which the anthropogenic cloud albedo forcing is calculated in IPCC assessments of climate (Fig. 5b). We estimated the annual mean anthropogenic cloud albedo forcing to lie between $-0.86 \mathrm{~W} \mathrm{~m}^{-2}$ and $-1.16 \mathrm{~W} \mathrm{~m}^{-2}$ (red symbols in Fig. 8; solid error bar in Fig. 9). Therefore, estimates of the anthropogenic cloud albedo forcing are sensitive to the uncertainties in the source strength of volcanic degassing even under the assumption that the flux remained constant between PI and PD. If we assume the volcanic sulphur flux strength changed between PI and PD within its plausible upper and lower limits, then the magnitude of the total cloud albedo forcing (i.e. volcanic and anthropogenic component) could lie between $-0.38 \mathrm{Wm}^{-2}$ and $-1.64 \mathrm{Wm}^{-2}$ (black symbols in Fig. 8; dashed error bar in Fig. 9) - comparable to the IPCC's anthropogenic cloud albedo forcing uncertainty estimate of $-0.3 \mathrm{~W} \mathrm{~m}^{-2}$ to $-1.8 \mathrm{~W} \mathrm{~m}^{-2}$ (Forster et al., 2007). Forster et al. (2007) did not explicitly account for this baseline effect, which suggests that (i) the uncertainty in the PI baseline is one of the largest contributors to the uncertainty of indirect radiative forcing estimates, and (ii) a more complete uncertainty analysis may significantly increase the IPCC uncertainty range.

Yuan et al. (2011) reported potentially substantial effects of volcanic aerosol from Hawaii on the regional hydrological cycle, which should be accounted for in a future uncertainty analysis of the aerosol indirect forcing of climate. Ultimately, large-eddy simulations that address volcanically induced cloud effects using detailed aerosol-cloud microphysical schemes in synergy with, for example, satellite retrievals should be employed (Yuan et al., 2011). Notwithstanding the above, reducing the uncertainty in estimates of the volcanic flux strength is essential to reduce the uncertainty in the magnitude of the indirect radiative forcing of climate. 
a) $\mathrm{Pl}$ no volcanic emissions

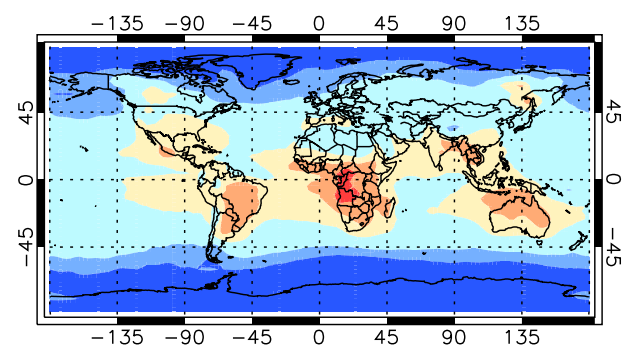

c) $\mathrm{Pl}$ incl. volcanic emissions

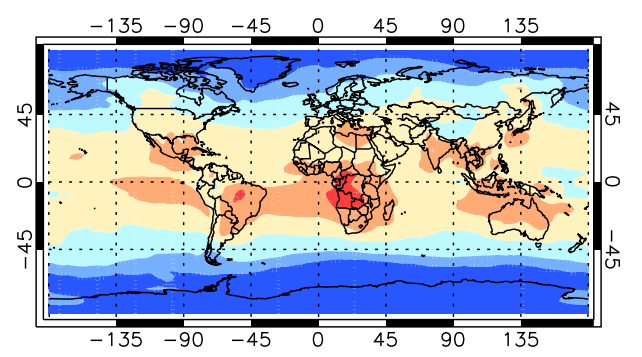

b) PD no volcanic emissions

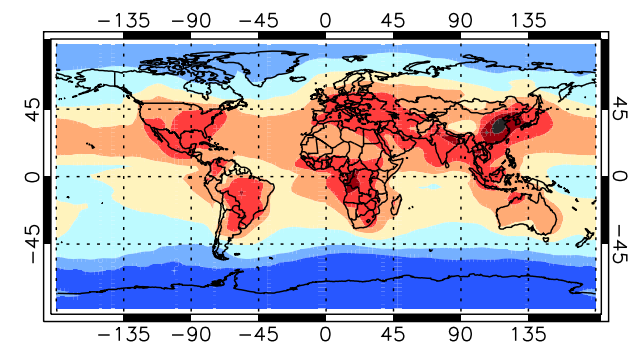

d) PD incl. volcanic emissions

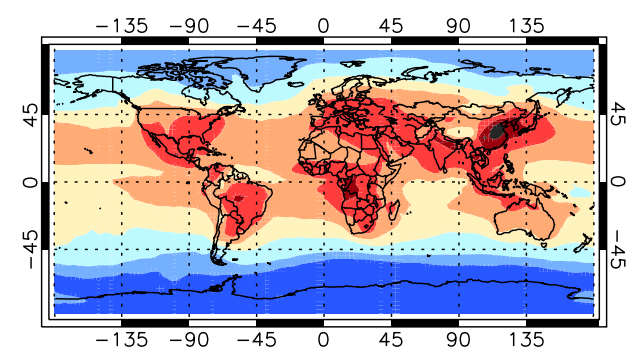

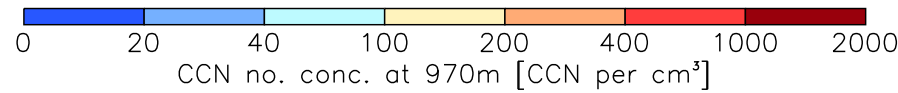

e) PI Change in $\mathrm{CCN}$

(volcanics MINUS no volcanics)

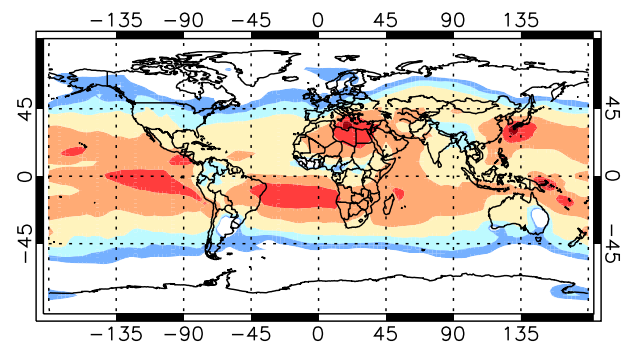

f) PD Change in $\mathrm{CCN}$ (volcanics MINUS no volcanics)

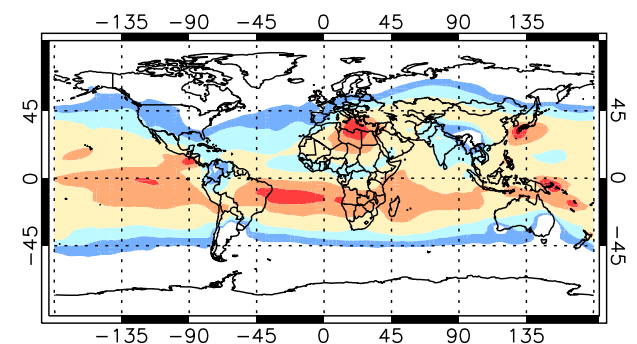

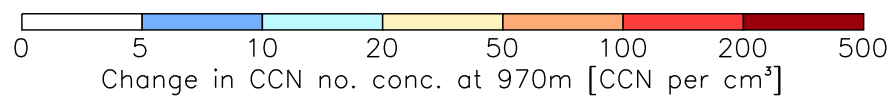

Fig. A1. Annual mean cloud condensation nuclei $(\mathrm{CCN})$ number concentrations $\left(\mathrm{cm}^{-3}\right)$ at $970 \mathrm{~m}$ altitude for the pre-industrial $(\mathrm{PI})$ era and present-day (PD) with: (a) PI simulation without volcanic emissions; (b) PD simulation without volcanic emissions; (c) PI simulation using the Andres and Kasgnoc (1998) volcanic emission inventory; and (d) PD simulation with volcanic emissions. The absolute difference in annual mean CCN concentrations for PI and PD are shown in panels (e) and (f), respectively. Here, CCN is counted as soluble particles with a dry radius larger than $35 \mathrm{~nm}$, which is equivalent to the particles that would activate into cloud droplets at $0.22 \%$ supersaturation.

Acknowledgements. We thank Joonas Merikanto for help with the pre-industrial emission inventories, Thomas J. Breider for the development of the coupled chemistry scheme, and Matthew $\mathrm{T}$. Woodhouse for providing further data on DMS-derived changes in $\mathrm{CCN}$ and useful discussions on an earlier version of the manuscript. We thank the reviewers and the Editor for their useful comments and suggestions. AS would like to thank David S. Stevenson and Daniel J. Morgan for their useful comments and discussions during the PhD viva, and Hans-F. Graf for very useful comments on an earlier version of this paper. We also thank Robert B. Simmon from NASA Earth Observatory for provision of the NASA satellite data. AS was funded through a University of Leeds $\mathrm{PhD}$ Research Scholarship and through NERC grant NE/I015612/1. AR was supported by the NERC grant NE/G005109/1. GWM was funded by the NERC National Centre for Atmospheric Science, and KSC and PMF are Royal Society Wolfson Merit Award Holders.

Edited by: V.-M. Kerminen 


\section{References}

Albrecht, B. A.: Aerosols, cloud microphysics, and fractional cloudiness, Science, 245, 1227-1230, 1989.

Allen, A. G., Oppenheimer, C., Ferm, M., Baxter, P. J., Horrocks, L. A., Galle, B., McGonigle, A. J. S., and Duffell, H. J.: Primary sulfate aerosol and associated emissions from Masaya Volcano, Nicaragua, J. Geophys. Res., 107, 4682, doi:10.1029/2002JD002120, 2002.

Andres, R. J. and Kasgnoc, A. D.: A time-averaged inventory of subaerial volcanic sulfur emissions, J. Geophys. Res., 103, 25251-25262, doi:10.1029/98JD02091, 1998.

Barahona, D., West, R. E. L., Stier, P., Romakkaniemi, S., Kokkola, H., and Nenes, A.: Comprehensively accounting for the effect of giant $\mathrm{CCN}$ in cloud activation parameterizations, Atmos. Chem. Phys., 10, 2467-2473, doi:10.5194/acp-10-24672010, 2010.

Baxter, P. J.: Impacts of eruptions on human health, in: Encyclopedia of Volcanoes, edited by: Sigurdsson, H., Houghton, B. F., McNutt, S. R., Rymer, H., and Stix, J., Academic Press, London, UK, 1035-1043, 2000.

Bond, T. C., Streets, D. G., Yarber, K. F., Nelson, S. M., Woo, J.H., and Klimont, Z.: A technology-based global inventory of black and organic carbon emissions from combustion, J. Geophys. Res., 109, D14203, doi:10.1029/2003JD003697, 2004.

Boucher, O. and Lohmann, U.: The sulfate-CCN-cloud albedo effect, a sensitivity study with two general circulation models, Tellus B, 47, 281-300, 1995.

Boulon, J., Sellegri, K., Hervo, M., and Laj, P.: Observations of nucleation of new particles in a volcanic plume, P. Natl. Acad. Sci. USA, 108, 12223-12226, doi:10.1073/pnas.1104923108, 2011.

Breider, T. J., Chipperfield, M. P., Richards, N. A. D., Carslaw, K. S., Mann, G. W., and Spracklen, D. V.: Impact of $\mathrm{BrO}$ on dimethylsulfide in the remote marine boundary layer, Geophys. Res. Lett., 37, L02807, doi:10.1029/2009GL040868, 2010.

Brock, C. A., Washenfelder, R. A., Trainer, M., Ryerson, T. B., Wilson, J. C., Reeves, J. M., Huey, L. G., Holloway, J. S., Parrish, D. D., Hübler, G., and Fehsenfeld, F. C.: Particle growth in the plumes of coal-fired power plants, J. Geophys. Res., 107, 4155, doi:10.1029/2001JD001062, 2002.

Carslaw, K. S., Boucher, O., Spracklen, D. V., Mann, G. W., Rae, J. G. L., Woodward, S., and Kulmala, M.: A review of natural aerosol interactions and feedbacks within the Earth system, Atmos. Chem. Phys., 10, 1701-1737, doi:10.5194/acp-10-17012010, 2010.

Chen, Y. and Penner, J. E.: Uncertainty analysis for estimates of the first indirect aerosol effect, Atmos. Chem. Phys., 5, 2935-2948, doi:10.5194/acp-5-2935-2005, 2005.

Chin, M. and Jacob, D. J.: Anthropogenic and natural contributions to tropospheric sulfate: a global model analysis, J. Geophys. Res., 101, 18691-18699, doi:10.1029/96JD01222, 1996.

Chipperfield, M. P.: New version of the TOMCAT/SLIMCAT offline chemical transport model: Intercomparison of stratospheric tracer experiments, Q. J. Roy. Meteor. Soc., 132, 1179-1203, doi:10.1256/qj.05.51, 2006.

Cofala, J., Amann, M., Klimont, Z., and Schopp, W.: Scenarios of World Anthropogenic Emissions of $\mathrm{SO}_{2}, \mathrm{NO}_{\mathrm{x}}$ and $\mathrm{CO}$ up to 2030, Internal report of the Transboundary Air Pollution Programme, International Institude for Applied Systems Analysis,
Laxenburg, Austria, 2005.

Dee, D. P., Uppala, S. M., Simmons, A. J., Berrisford, P., Poli, P., Kobayashi, S., Andrae, U., Balmaseda, M. A., Balsamo, G., Bauer, P., Bechtold, P., Beljaars, A. C. M., van de Berg, L., Bidlot, J., Bormann, N., Delsol, C., Dragani, R., Fuentes, M., Geer, A. J., Haimberger, L., Healy, S., Hersbach, H., Hólm, E. V., Isaksen, L., Kållberg, P., Köhler, M., Matricardi, M., McNally, A. P., Monge-Sanz, B. M., Morcrette, J.-J., Peubey, C., de Rosnay, P., Tavolato, C., Thépaut, J.-N., and Vitart, F.: The ERAInterim reanalysis: Configuration and performance of the data assimilation system, Q. J. Roy. Meteorol. Soc., 133, 1972-1990, doi:10.1002/qj.828, 2011.

Delmelle, P., Stix, J., Baxter, P. J., Garcia-Alvarez, J., and Barquero, J. Atmospheric dispersion, environmental effects and potential health hazard associated with the low-altitude gas plume of Masaya volcano, Nicaragua, B. Volcanol., 64, 423-434, doi:10.1007/s00445-002-0221-6, 2002.

Dentener, F., Kinne, S., Bond, T., Boucher, O., Cofala, J., Generoso, S., Ginoux, P., Gong, S., Hoelzemann, J. J., Ito, A., Marelli, L., Penner, J. E., Putaud, J.-P., Textor, C., Schulz, M., van der Werf, G. R., and Wilson, J.: Emissions of primary aerosol and precursor gases in the years 2000 and 1750 prescribed data-sets for AeroCom, Atmos. Chem. Phys., 6, 43214344, doi:10.5194/acp-6-4321-2006, 2006.

Edwards, J. M. and Slingo, A.: Studies with a flexible new radiation code - I: Choosing a configuration for a large-scale model, Q. J. Roy. Meteor. Soc., 122, 689-719, doi:10.1002/qj.49712253107, 1996.

Forster, P., Ramaswamy, V., Artaxo, P., Berntsen, T., Betts, R., Fahey, D. W., Haywood, J., Lean, J., Lowe, D. C., Myhre, G., Nganga, J., Prinn, R., Raga, G., Schulz, M., and Van Dorland, R.: Changes in atmospheric constituents and in radiative forcing, in: Climate Change 2007: The Physical Science Basis, Contribution of Working Group I to the Fourth Assessment Report of the Intergovernmental Panel on Climate Change, edited by: Solomon, S., Qin, D., Chen, Z., Manning, M., Marquis, M., Averyt, K. B., Tignor, M., and Miller, H. L., Cambridge University Press, Cambridge, UK and New York, NY, USA, 129-234, 2007.

Fountoukis, C., Nenes, A., Meskhidze, N., Bahreini, R., Conant, W. C., Jonsson, H., Murphy, S., Sorooshian, A., Varutbangkul, V., Brechtel, F., Flagan, R. C., and Seinfeld, J. H.: Aerosol-cloud drop concentration closure for clouds sampled during the International Consortium for Atmospheric Research on Transport and Transformation 2004 campaign, J. Geophys. Res., 112, D10S30, doi:10.1029/2006JD007272, 2007.

Gassó, S.: Satellite observations of the impact of weak volcanic activity on marine clouds, J. Geophys. Res., 113, D14S19, doi:10.1029/2007JD009106, 2008.

Gong, S. L.: A parameterization of sea-salt aerosol source function for sub- and super-micron particles, Global Biogeochem. Cy., 17, 1097, doi:10.1029/2003GB002079, 2003.

Graf, H.-F., Feichter, J., and Langmann, B. R.: Volcanic sulfur emissions: estimates of source strength and its contribution to the global sulfate distribution, J. Geophys. Res., 102, 727-738, doi:10.1029/96JD03265, 1997.

Graf, H.-F., Langmann, B., and Feichter, J.: The contribution of Earth degassing to the atmospheric sulfur budget, Chem. Geol., 147, 131-145, doi:10.1016/S0009-2541(97)00177-0, 1998. 
Guenther, A., Hewitt, C. N., Erickson, D., Fall, R., Geron, C., Graedel, T., Harley, P., Klinger, L., Lerdau, M., McKay, W. A., Pierce, T., Scholes, B., Steinbrecher, R., Tallamraju, R., Taylor, J., and Zimmerman, P.: A global model of natural volatile organic compound emissions, J. Geophys. Res., 100, 8873-8892, doi:10.1029/94JD02950, 1995.

Gultepe, I. and Isaac, G. A.: Scale effects on averaging of cloud droplet and aerosol number concentrations: observations and models, J. Climate, 12, 1268-1279, 1999.

Gunson, J. R., Spall, S. A., Anderson, T. R., Jones, A., Totterdell, I. J., and Woodage, M. J.: Climate sensitivity to ocean dimethylsulphide emissions, Geophys. Res. Lett., 33, L07701, doi:10.1029/2005GL024982, 2006.

Halmer, M., Schmincke, H., and Graf, H.-F.: The annual volcanic gas input into the atmosphere, in particular into the stratosphere, a global data-set for the past 100 years, J. Volcanol. Geoth. Res., 115, 511-528, doi:10.1016/S0377-0273(01)00318-3, 2002.

Hansen, J., Sato, M., and Ruedy, R.: Radiative forcing and climate response, J. Geophys. Res., 102, 6831-6864, doi:10.1029/96JD03436, 1997.

Karydis, V. A., Kumar, P., Barahona, D., Sokolik, I. N., and Nenes, A.: On the effect of dust particles on global cloud condensation nuclei and cloud droplet number, J. Geophys. Res., 116, D23204, doi:10.1029/2011JD016283, 2011.

Kellogg, W. W., Cadle, R. D., Allen, E. R., Lazrus, A. L., and Martell, E. A.: The sulfur cycle, Science, 175, 587-596, 1972.

Kettle, A. J. and Andreae, M. O.: Flux of dimethylsulfide from the oceans: a comparison of updated data sets and flux models, J. Geophys. Res., 105, 26793-26808, doi:10.1029/2000JD900252, 2000.

Klein, S. A. and Hartmann, D. L.: The seasonal cycle of low stratiform clouds, J. Climate, 6, 1587-1606, 1993.

Kulmala, M., Laaksonen, A., and Pirjola, L.: Parameterization for sulfuric acid/water nucleation rates, J. Geophys. Res., 108, 83018307, doi:10.1029/97JD03718, 1998.

Kump, L. R. and Pollard, D.: Amplification of Cretaceous warmth by biological cloud feedbacks, Science, 320, p. 195, 2008.

Lamarque, J.-F., Bond, T. C., Eyring, V., Granier, C., Heil, A., Klimont, Z., Lee, D., Liousse, C., Mieville, A., Owen, B., Schultz, M. G., Shindell, D., Smith, S. J., Stehfest, E., Van Aardenne, J., Cooper, O. R., Kainuma, M., Mahowald, N., McConnell, J. R., Naik, V., Riahi, K., and van Vuuren, D. P.: Historical (1850-2000) gridded anthropogenic and biomass burning emissions of reactive gases and aerosols: methodology and application, Atmos. Chem. Phys., 10, 7017-7039, doi:10.5194/acp10-7017-2010, 2010.

Lambert, G., Le Cloarec, M. F., and Pennisi, M.: Volcanic output of $\mathrm{SO}_{2}$ and trace metals: a new approach, Geochim. Cosmochim. Ac., 52, 39-42, 1988.

Langmann, B., Herzog, M., and Graf, H.-F.: Radiative forcing of climate by sulfate aerosols as determined by a regional circulation chemistry transport model, Atmos. Environ., 32, 2757-2768, doi:10.1016/s1352-2310(98)00028-4, 1998.

Lohmann, U. and Feichter, J.: Global indirect aerosol effects: a review, Atmos. Chem. Phys., 5, 715-737, doi:10.5194/acp-5-7152005, 2005.

Luo, G. and Yu, F.: Sensitivity of global cloud condensation nuclei concentrations to primary sulfate emission parameterizations, Atmos. Chem. Phys., 11, 1949-1959, doi:10.5194/acp-11-
1949-2011, 2011.

Mahowald, N., Ward, D., Kloster, S., Flanner, M., Heald, C., Heavens, N., Hess, P., Lamarque, J.-F., and Chuang, P.: Aerosol impacts on climate and biogeochemistry, Annual Reviews of Environment and Resources, 36, 45-74, 2011.

Mann, G. W., Carslaw, K. S., Spracklen, D. V., Ridley, D. A., Manktelow, P. T., Chipperfield, M. P., Pickering, S. J., and Johnson, C. E.: Description and evaluation of GLOMAP-mode: a modal global aerosol microphysics model for the UKCA composition-climate model, Geosci. Model Dev., 3, 519-551, doi:10.5194/gmd-3-519-2010, 2010.

Mann, G. W., Carslaw, K. S., Ridley, D. A., Spracklen, D. V., Pringle, K. J., Merikanto, J., Korhonen, H., Schwarz, J. P., Lee, L. A., Manktelow, P. T., Woodhouse, M. T., Schmidt, A., Breider, T. J., Emmerson, K. M., Reddington, C. L., Chipperfield, M. P., and Pickering, S. J.: Intercomparison of modal and sectional aerosol microphysics representations within the same 3-D global chemical transport model, Atmos. Chem. Phys., 12 4449-4476, doi:10.5194/acp-12-4449-2012, 2012.

Martin, R. S., Mather, T. A., Pyle, D. M., Power, M., Allen, A. G., Aiuppa, A., Horwell, C. J., and Ward, E. P. W.: Composition-resolved size distributions of volcanic aerosols in the Mt. Etna plumes, J. Geophys. Res., 113, D17211, doi:10.1029/2007JD009648, 2008.

Martucci, G., Ovadnevaite, J., Ceburnis, D., Berresheim, H., Varghese, S., Martin, D., Flanagan, R., and O’Dowd, C. D.: Impact of volcanic ash plume aerosol on cloud microphysics, Atmos. Environ., 48, 205-218, doi:10.1016/j.atmosenv.2011.12.033, 2012.

Mather, T. A., Allen, A. G., Oppenheimer, C., Pyle, D. M., and McGonigle, A. J. S.: Size-resolved characterisation of soluble ions in the particles in the tropospheric plume of Masaya Volcano, Nicaragua: origins and plume processing, J. Atmos. Chem., 46, 207-237, doi:10.1023/A:1026327502060, 2003a.

Mather, T. A., Pyle, D. M., and Oppenheimer, C.: Tropospheric Volcanic Aerosol, in: Volcanism and the Earth's Atmosphere, American Geophysical Union (AGU), Washington, DC, USA, 189212, 2003 b.

Mather, T. A., Tsanev, V. I., Pyle, D. M., McGonigle, A. J. S., Oppenheimer, C., and Allen, A. G.: Characterization and evolution of tropospheric plumes from Lascar and Villarrica volcanoes, Chile, J. Geophys. Res., 109, D21303, doi:10.1029/2004JD004934, 2004.

Mather, T. A., McCabe, J. R., Rai, V. K., Thiemens, M. H., Pyle, D. M., Heaton, T. H. E., Sloane, H. J., and Fern, G. R.: Oxygen and sulfur isotopic composition of volcanic sulfate aerosol at the point of emission, J. Geophys. Res., 111, D18205, doi:10.1029/2005JD006584, 2006.

Mather, T. A.: Volcanism and the atmosphere: the potential role of the atmosphere in unlocking the reactivity of volcanic emissions, Philos. T. Roy. Soc. A, 366, 4581-4595, doi:10.1098/rsta.2008.0152, 2008.

Mather, T. A., Witt, M. L. I., Pyle, D. M., Quayle, B. M., Aiuppa, A., Bagnato, E., Martin, R. S., Sims, K. W. W., Edmonds, M., Sutton, A. J., and Ilyinskaya, E.: Halogens and trace metal emissions from the ongoing 2008 summit eruption of Kilauea volcano, Hawai ‘i, Geochim. Cosmochim. Acta, 83, 292-323, 2012.

Merikanto, J., Spracklen, D. V., Pringle, K. J., and Carslaw, K. S.: Effects of boundary layer particle formation on cloud droplet number and changes in cloud albedo from 1850 to 2000, Atmos. 
Chem. Phys., 10, 695-705, doi:10.5194/acp-10-695-2010, 2010.

Nenes, A. and Seinfeld, J. H.: Parameterization of cloud droplet formation in global climate models, J. Geophys. Res., 108, 4415, doi:10.1029/2002JD002911, 2003.

Nightingale, P. D., Malin, G., Law, C. S., Watson, A. J., Liss, P. S., Liddicoat, M. I., Boutin, J., and Upstill-Goddard, R. C.: In situ evaluation of air-sea gas exchange - parameterizations using novel conservative and volatile tracers, Global Biogeochem. Cy., 14, 373-387, doi:10.1029/1999GB900091, 2000.

Nober, F. J., Graf, H. F., and Rosenfeld, D.: Sensitivity of the global circulation to the suppression of precipitation by anthropogenic aerosols, Global Planet. Change, 37, 57-80, doi:10.1016/S09218181(02)00191-1, 2003.

Oppenheimer, C., Scaillet, B., and Martin, R. S.: Sulfur degassing from volcanoes: source conditions, surveillance, plume chemistry and Earth system impacts, Rev. Mineral. Geochem., 73, 363-421, doi:10.2138/rmg.2011.73.13, 2011.

Peng, Y., Lohmann, U., and Leaitch, R.: Importance of vertical velocity variations in the cloud droplet nucleation process of marine stratus clouds, J. Geophys. Res., 110, D21213, doi:10.1029/2004JD004922, 2005.

Penner, J. E., Andrea, M., Annegarn, H., Barrie, L., Feichter, J., Hegg, D., Jayaraman, A., Leaitch, R., Murphy, D., Nganga, J., Pitari, G., et al.: The Scientific Basis. Contribution of Working Group I to the Third Assessment Report of the Intergovernmental Panel on Climate Change, in: Climate Change 2001, edited by: Houghton, J. T., Ding, Y., and et al., Cambridge University Press, Cambridge and New York, USA, 2001.

Pfeffer, M. A., Langmann, B., and Graf, H.-F.: Atmospheric transport and deposition of Indonesian volcanic emissions, Atmos. Chem. Phys., 6, 2525-2537, doi:10.5194/acp-6-2525-2006, 2006.

Pringle, K. J., Carslaw, K. S., Spracklen, D. V., Mann, G. M., and Chipperfield, M. P.: The relationship between aerosol and cloud drop number concentrations in a global aerosol microphysics model, Atmos. Chem. Phys., 9, 4131-4144, doi:10.5194/acp-94131-2009, 2009.

Rap, A., Forster, P. M., Jones, A., Boucher, O., Haywood, J. M., Bellouin, N., and De Leon, R. R.: Parameterization of contrails in the UK Met Office Climate Model, J. Geophys. Res., 115, D10205, doi:10.1029/2009jd012443, 2010.

Robock, A.: Volcanic eruptions and climate, Rev. Geophys., 38, 191-219, doi:10.1029/1998RG000054, 2000.

Robock, A.: Blowin' in the wind: research priorities for climate effects of volcanic eruptions, Eos Trans. AGU, 83, 472, doi:10.1029/2002EO000333, 2002.

Roelofs, G. J., Stier, P., Feichter, J., Vignati, E., and Wilson, J.: Aerosol activation and cloud processing in the global aerosolclimate model ECHAM5-HAM, Atmos. Chem. Phys., 6, 23892399, doi:10.5194/acp-6-2389-2006, 2006.

Rossow, W. B. and Schiffer, R. A.: Advances in understanding clouds from ISCCP, B. Am. Meteorol. Soc., 80, 2261-2287, 1999.

Schäfer, K., Thomas, W., Peters, A., Ries, L., Obleitner, F., Schnelle-Kreis, J., Birmili, W., Diemer, J., Fricke, W., Junkermann, W., Pitz, M., Emeis, S., Forkel, R., Suppan, P., Flentje, H., Gilge, S., Wichmann, H. E., Meinhardt, F., Zimmermann, R., Weinhold, K., Soentgen, J., Münkel, C., Freuer, C., and Cyrys, J.: Influences of the 2010 Eyjafjallajökull volcanic plume on air quality in the northern Alpine region, Atmos. Chem. Phys., 11, 8555-8575, doi:10.5194/acp-11-8555-2011, 2011.

Schmidt, A., Carslaw, K. S., Mann, G. W., Wilson, M., Breider, T. J., Pickering, S. J., and Thordarson, T.: The impact of the 17831784 AD Laki eruption on global aerosol formation processes and cloud condensation nuclei, Atmos. Chem. Phys., 10, 60256041, doi:10.5194/acp-10-6025-2010, 2010.

Schmidt, A., Ostro, B., Carslaw, K. S., Wilson, M., Thordarson, T., Mann, G. W., and Simmons, A. J.: Excess mortality in Europe following a future Laki-style Icelandic eruption, P. Natl. Acad. Sci. USA, 108, 15710-15715, doi:10.1073/pnas.1108569108, 2011.

Simkin, T.: Terrestrial volcanism in space and time, Annu. Rev. Earth Pl. Sci., 21, 427-452, doi:10.1146/annurev.ea.21.050193.002235, 1993.

Smith, S. J., van Aardenne, J., Klimont, Z., Andres, R. J., Volke, A., and Delgado Arias, S.: Anthropogenic sulfur dioxide emissions: 1850-2005, Atmos. Chem. Phys., 11, 1101-1116, doi:10.5194/acp-11-1101-2011, 2011.

Spracklen, D. V., Pringle, K. J., Carslaw, K. S., Chipperfield, M. P., and Mann, G. W.: A global off-line model of sizeresolved aerosol microphysics: I. Model development and prediction of aerosol properties, Atmos. Chem. Phys., 5, 2227 2252, doi:10.5194/acp-5-2227-2005, 2005a.

Spracklen, D. V., Pringle, K. J., Carslaw, K. S., Chipperfield, M. P., and Mann, G. W.: A global off-line model of size-resolved aerosol microphysics: II. Identification of key uncertainties, Atmos. Chem. Phys., 5, 3233-3250, doi:10.5194/acp-5-3233-2005, 2005 b.

Spracklen, D. V., Carslaw, K. S., Kulmala, M., Kerminen, V.-M., Mann, G. W., and Sihto, S.-L.: The contribution of boundary layer nucleation events to total particle concentrations on regional and global scales, Atmos. Chem. Phys., 6, 5631-5648, doi:10.5194/acp-6-5631-2006, 2006.

Spracklen, D. V., Carslaw, K. S., Merikanto, J., Mann, G. W., Reddington, C. L., Pickering, S., Ogren, J. A., Andrews, E., Baltensperger, U., Weingartner, E., Boy, M., Kulmala, M., Laakso, L., Lihavainen, H., Kivekäs, N., Komppula, M., Mihalopoulos, N., Kouvarakis, G., Jennings, S. G., O’Dowd, C., Birmili, W., Wiedensohler, A., Weller, R., Gras, J., Laj, P., Sellegri, K., Bonn, B., Krejci, R., Laaksonen, A., Hamed, A., Minikin, A., Harrison, R. M., Talbot, R., and Sun, J.: Explaining global surface aerosol number concentrations in terms of primary emissions and particle formation, Atmos. Chem. Phys., 10, 47754793, doi:10.5194/acp-10-4775-2010, 2010.

Spracklen, D. V., Carslaw, K. S., Pöschl, U., Rap, A., and Forster, P. M.: Global cloud condensation nuclei influenced by carbonaceous combustion aerosol, Atmos. Chem. Phys., 11, 9067-9087, doi:10.5194/acp-11-9067-2011, 2011.

Stevenson, D. S., Johnson, C. E., Collins, W. J., and Derwent, R. G.: The tropospheric sulphur cycle and the role of volcanic $\mathrm{SO}_{2}$, Geol. Soc. Spec. Publ., 6, 295-305, 2003a.

Stevenson, D. S., Johnson, C. E., Highwood, E. J., Gauci, V., Collins, W. J., and Derwent, R. G.: Atmospheric impact of the 1783-1784 Laki eruption: Part I Chemistry modelling, Atmos. Chem. Phys., 3, 487-507, doi:10.5194/acp-3-487-2003, 2003 b.

Stier, P., Feichter, J., Kinne, S., Kloster, S., Vignati, E., Wilson, J., Ganzeveld, L., Tegen, I., Werner, M., Balkanski, Y., Schulz, M., Boucher, O., Minikin, A., and Petzold, A.: The aerosol-climate 
model ECHAM5-HAM, Atmos. Chem. Phys., 5, 1125-1156, doi:10.5194/acp-5-1125-2005, 2005.

Stockwell, D. Z. and Chipperfield, M. P.: A tropospheric chemicaltransport model: development and validation of the model transport schemes, Q. J. Roy. Meteor. Soc., 125, 1747-1783, doi:10.1002/qj.49712555714, 1999.

Textor, C., Graf, H. F. T. C., and Robock, A.: Emissions from volcanoes, in: Emissions of Chemical Compounds and Aerosols in the Atmosphere, edited by: Granier, C., Artaxo, P., and Reeves, C., Kluwer, Dordrecht, The Netherlands, 269-303, 2004.

Thomas, M. A., Suntharalingam, P., Pozzoli, L., Rast, S., Devasthale, A., Kloster, S., Feichter, J., and Lenton, T. M.: Quantification of DMS aerosol-cloud-climate interactions using the ECHAM5-HAMMOZ model in a current climate scenario, Atmos. Chem. Phys., 10, 7425-7438, doi:10.5194/acp-10-74252010, 2010.

Timmreck, C., Lorenz, S. J., Crowley, T. J., Kinne, S., Raddatz, T. J., Thomas, M. A., and Jungclaus, J. H.: Limited temperature response to the very large AD 1258 volcanic eruption, Geophys. Res. Lett., 36, L21708, doi:10.1029/2009GL040083, 2009.

Timmreck, C., Graf, H.-F., Lorenz, S. J., Niemeier, U., Zanchettin, D., Matei, D., Jungclaus, J. H., and Crowley, T. J.: Aerosol size confines climate response to volcanic super-eruptions, Geophys. Res. Lett., 37, L24705, doi:10.1029/2010GL045464, 2010.

Tu, F. H., Thornton, D. C., Bandy, A. R., Carmichael, G. R., Tang, Y., Thornhill, K. L., Sachse, G. W., and Blake, D. R.: Longrange transport of sulfur dioxide in the Central Pacific, J. Geophys. Res., 109, D15S08, doi:10.1029/2003jd004309, 2004.

Twomey, S.: The influence of pollution on the shortwave albedo of clouds, J. Atmos. Sci., 34(7), 1149-1152, 1977.

Uppala, S. M., Kållberg, P. W., Simmons, A. J., Andrae, U., Bechtold, V. D. C., Fiorino, M., Gibson, J. K., Haseler, J., Hernandez, A., Kelly, G. A., Li, X., Onogi, K., Saarinen, S., Sokka, N., Allan, R. P., Andersson, E., Arpe, K., Balmaseda, M. A., Beljaars, A. C. M., Berg, L. V. D., Bidlot, J., Bormann, N., Caires, S., Chevallier, F., Dethof, A., Dragosavac, M., Fisher, M., Fuentes, M., Hagemann, S., Hólm, E., Hoskins, B. J., Isaksen, L., Janssen, P. A. E. M., Jenne, R., McNally, A. P., Mahfouf, J. F., Morcrette, J. J., Rayner, N. A., Saunders, R. W., Simon, P., Sterl, A., Trenberth, K. E., Untch, A., Vasiljevic, D., Viterbo, P., and Woollen, J.: The ERA-40 re-analysis, Q. J. Roy. Meteor. Soc., 131, 2961-3012, doi:10.1256/qj.04.176, 2005.
Van der Werf, G. R., Randerson, J. T., Collatz, G. J., and Giglio, L.: Carbon emissions from fires in tropical and subtropical ecosystems, Global Change Biol., 9, 547-562, doi:10.1046/j.13652486.2003.00604.x, 2003.

Ward, D. S., Kloster, S., Mahowald, N. M., Rogers, B. M., Randerson, J. T., and Hess, P. G.: The changing radiative forcing of fires: global model estimates for past, present and future, Atmos. Chem. Phys. Discuss., 12, 10535-10621, doi:10.5194/acpd-1210535-2012, 2012.

Woodhouse, M. T., Carslaw, K. S., Mann, G. W., Vallina, S. M., Vogt, M., Halloran, P. R., and Boucher, O.: Low sensitivity of cloud condensation nuclei to changes in the sea-air flux of dimethyl-sulphide, Atmos. Chem. Phys., 10, 7545-7559, doi:10.5194/acp-10-7545-2010, 2010.

Woodhouse, M. T., Mann, G. W., Carslaw, K. S., Boucher, O.: Sensitivity of cloud condensation nuclei to regional changes in dimethyl-sulphide emissions, submitted to Atmos. Chem. Phys. Discuss., 2012.

Yuan, T., Remer, L. A., and Yu, H.: Microphysical, macrophysical and radiative signatures of volcanic aerosols in trade wind cumulus observed by the A-Train, Atmos. Chem. Phys., 11, 71197132, doi:10.5194/acp-11-7119-2011, 2011. 